\title{
The Challenges of Modern Economy on the Competencies of Knowledge Workers
}

\author{
John Muzam ${ }^{1,2}$ \\ Received: 22 August 2021 / Accepted: 24 January 2022 \\ (C) The Author(s) 2022
}

\begin{abstract}
The modern environment has seen drastic changes; competency management, a core corporate strategy that enables talents to be in line with corporate objectives, is becoming a crucial aspect in solving organisational challenges and a vital source of competitive advantage. Human resource management (HRM) adds value by developing a better competency approach when it fully understands the required competencies for its knowledge workers. The purpose of this article is to understand the overall perspective (required competencies, challenges, and skills gaps) of knowledge workers' competencies in the modern economy. An expert panel research method was used, as it allows for more complex research that addresses both observed and unobserved determinants of skill and competency requirements. Based on competency management, the result indicates that critical thinking, interpersonal and emotional skills, inspection and monitoring skills, and basic digital skills are the key competencies required. The resulting consequences of the lack of these competencies are also mentioned.
\end{abstract}

Keywords Knowledge workers $\cdot$ Competencies $\cdot$ Skills $\cdot$ Modern economy

\section{Introduction}

In the last two decades, the global economy has experienced tremendous changes due to various factors such as technological advancement, globalisation, changes in the nature of work, and management systems. The economy has witnessed a shift from the traditional production system into a more service-oriented economy known as the 'knowledge economy' (modern economy). The modern economy term is used to describe the rapidly changing global economy pace spurred by the use of information

John Muzam

john.muzam@polsl.pl; johnmuzam0@gmail.com

1 Doctoral School, Silesian University of Technology, Gliwice, Poland

2 Faculty of Organization and Management, Department of Management and Logistics, Silesian University of Technology, ul. Roosevelta 26-28, 41-800 Zabrze, Poland 
and communication technologies (ICT) (Tapscott, 1996). The modern economy has witnessed rapid changes in almost every economic sector coupled with long-term growth and lower inflationary pressure (Stiroh, 1999). This new economy applies human know-how in almost every economic sector (Servoz, 2019; Tapscott, 1996; Choong \& Leung, 2021). Healy (2002) indicated that one of the most crucial features in the new economy is changes in the creative industry, an industry in which people work with their brains. It is also described as an economy in which people think for a living (Davenport, 2005). Currently, the skills and creativity of workers are becoming more critical than physical labour (Drucker, 1969), leading to the rise of knowledge workers (KWrs) (Davenport, 2008; Spencer et al., 1993). According to Gartner's report (Roth, 2019), the global population of KWrs has exceeded one billion. The future of work will witness the continuous rise of knowledge work and KWrs (Kudyba et al., 2020). Therefore, organisations will need to develop or enhance their current skills and strategies due to the global market challenge.

\section{Understanding Knowledge Workers}

Peter F. Drucker described knowledge work as productive work based on the intellect rather than the manual hands of an individual. He postulated that the challenge of management in the new economy would focus on making KWrs more productive (Drucker, 1969). The KWrs are a non-homogenous set of individuals segmented based on some degree of collaboration and different competency levels required to do their job (Acsente, 2010; Hammer et al., 2004). Jemielniak (2012a) stated that the shift in the modern economy is the move from general knowledge to localised knowledge, leading to a new type of professionals with different types of organisational privilege. In order to distinguish KWrs from other work requiring knowledge, Hammer et al. (2004) argued that KWrs should be viewed not as isolated independent workers but as individual workers whose tasks are directly interconnected to the organisational business process. Several definitions of KWrs exist in the literature (Horibe, 1999; Pyöriä, 2005; Peng, 2009; Acsente, 2010; Edmonton, 2011; Jemielniak, 2012b; Nickols, 2016; Baena et al., 2017; Surawski, 2019; De Sordi et al., 2021).

Nevertheless, no consensus definition is available for the term KWr. The fact that the term 'KWrs' has several definitions poses a challenge to the effective management of KWrs in modern organisations (Acsente, 2010). According to De Sordi et al. (2021), two views exist. One group views the prerequisite of KWrs as the generation, creation, and advancement of knowledge (scientists or researchers). In contrast, others see KWrs as workers who use and apply organisational knowledge (operational employees). Surawski (2019) compared the term KWrs with other workers such as white collars and experts. The author concluded that one key feature of the KWrs is that they work mainly with symbols and transform these symbols into cognitive processes, which create added value. For this study, the definition is viewed from a general perspective, implying looking at KWrs as autonomous individuals whose work requires a high level of knowledge and perform complex tasks which primarily focus on problem-solving.

The KWrs are responsible for spearheading organisational growth and innovations (Horibe, 1999; Jemielniak, 2012b; Joseph, 2004). Unlike ordinary workers, 
they require different skills and competencies due to their job complexity (Spencer et al., 1993). Possessing the necessary skills, knowledge, and competencies is vital to creating unique organisational competencies. Building these competencies in a dynamic environment is very challenging. Workers have to learn on the job and solve problems that arise at the moment, as problems encountered at the workplace cannot be predicted. Hence, adequate understanding and effective management of competencies are required to perform the job. These competencies or soft assets residing inside the firm cannot be traded or acquired. Instead, they must be built (Teece et al., 1997). Building the right competence provides the organisation opportunities to adapt to emerging markets (Prahalad \& Hamel, 1997). Therefore, the fundamental challenge is how to build the right competence.

In a traditional environment, work has been predefined and requires that workers get training before completing the job. The work environment has witnessed a drastic change in the modern economy. Competency management, a core corporate strategy that enables talents to align with corporate objectives, is crucial in solving these challenges (Boyatzis \& Dubuc, 1982; Ddi, 2015). In modern organisations, the competencies of the firms' KWrs are a vital source of competitive advantage (Alvesson, 2004). Therefore, knowing what they are and how they can be achieved is necessary. Human resource management (HRM) adds value by developing a better competency approach. The required competencies for KWrs are fully understood. These requirements account for the main study objectives, namely to understand the overall situation (required competencies, challenges, and skills gaps) of KWrs' competencies in the modern economy. This study stands on the ground of HRM and supports the view that the effective utilisation of competencies offers a competitive advantage in a dynamic environment (Alvesson, 2004; Boyatzis \& Dubuc, 1982). Identifying, retention, and deploying KWrs' competencies via talent management are particular values to organisations (Armstrong \& Taylor, 2017). The study supports the competency-based human resource model, where contrary to traditional human resources (HR) models, emphasis is placed on competencies rather than taskbased. The goal of HR is to discover the competencies of KWrs and support them in achieving the goal (Sienkiewicz et al., 2014).

Chen and Edgington (2005) revealed how investing in KWrs' competency can create value. Although the study focuses on KWrs' analytical skills, it explores how knowledge creation over time can increase value via its competency approach by matching skills to task complexities. Other studies, such as Tsai et al. (2010), revealed how KWrs' interpersonal skills impact the ability to innovate. Pont (2001) showed the competencies for the knowledge economy, whereas Hendarman and Tjakraatmadja (2012) examined the skills of KWrs in the twenty-first century by revealing the relationship between hard and soft skills. Nonetheless, limited or no empirical studies exist on the current challenges and the required competencies of KWrs in a dynamic environment (Acsente, 2010; De Sordi et al., 2021; Surawski, 2019). A recent study by Koehorst (2020) explored the Dutch creative industry and attempted to explain the desired competencies of KWrs in the modern economy but mainly focused on digital skills in the creative industry. Several existing works of literature concentrate on single skills, such as analytical skills, trust, motivation, or KWr retention (Bontje et al., 2017; Khazaei, 2019a; Sjöblom, 2020; Colomo-Palacios et al., 2010). Other 
questions remain unanswered, such as the current organisational challenges in finding the required competencies and the measures taken to solve these challenges.

This article attempts to answer some of these questions. In order to find the answers, an expert panel research method has been utilised. The expert panel research method is vital as it allows for a more complex study in which observed and unobserved determinants of skill and competencies requirements could be addressed (Bakule et al., 2016). The method offers a diverse and synthesised perspective and foresight on studying the issue (Popper, 2008). Thus, the study aimed to answer the following main questions:

i. What are the required competencies of KWrs from the modern economy perspective, and how these competencies could be acquired?

ii. What are the current organisational challenges in terms of finding a $\mathrm{KWr}$ resource with the required competencies?

iii. What KWrs competencies would be required in the future?

By answering these questions from the competency management position, the findings indicated that critical thinking, interpersonal and emotional skills, inspecting, and monitoring skills top the list of required competencies. The consequences of the lack of these competencies are also mentioned. The Pareto analysis revealed the aspect of skill category that an organisation may focus on overcoming current challenges regarding KWrs competencies. The study begins with theoretical background by presenting the new economy and the observed changes, the economic perspective of change, and changes in the modern workplace. Next, the methods, results, discussions, and conclusions were presented.

\section{The New Economy and Its Impact}

\section{Approach to Innovation in Organisations in a Modern Economy}

The modern economy has witnessed a radical shift in the way innovation is obtained and managed. In an old economic setting, innovation is a purely linear process. Innovation is moving towards information obtained from the market analysis via research and development (R\&D) to a systemic integration of a network of processes and now an open and collaborative network focusing on individual networks at the core front (Kotsemir \& Meissner, 2013; Dubina et al., 2012; Carayannis \& Campbell, 2011). The modern economy has seen continuous growth of the open resource management approach (Kraken et al., 2020). A popular strategy among corporations in the information industry, such as Facebook, Apple, IBM, and Google, offers many possibilities for value creation and knowledge combinations (Schoder et al., 2019). The strategy is contrary to the conventional resource-based theory, which emphasises closeness or protection of resources to gain competitive advantage (Grant, 1991; Schoder et al., 2019; Wernerfelt, 1984).

In the old economy management, entrepreneurs make decisions based on predefined goals and anticipated risks. The actions of the individuals are constructed around these goals and predefined paths. A belief exists that the firm can take control 
of the environment using predefined strategies based on informed markets analysis. Nevertheless, in a highly dynamic environment, the approach has changed as a high rate of uncertainty prevail. A KWr must be more creative and flexible enough to make decisions based on diverse, dynamic techniques such as sense-making and innovative approaches rather than functional or substantive rationality (Cunningham et al., 2002). As no pre-existing pattern subsists, the emerging markets are constantly changing. Hence, traditional market indicators are becoming less reliable, and individuals must devise alternative methods to handle emerging issues. The KWrs must be able to 'sense' the situation and apply just-in-time solutions to respond immediately. As multiple answers are available to solve the emerging issues, employees must possess the capacity to gather the right and appropriate answers to the problem (Snowden \& Boone, 2007).

\section{The Flow of Information}

The new economy is an information flow and knowledge-intensive economy. Most data flow is intangible and performed via electronic mediums such as emails, electronic data interchanges (EDI), and social media. While the traditional economy is more capital and labour intensive, data flow is mainly tangible and flows via physical means, such as postal services, checks, and other methods. According to Manyika et al. (2016), data flow generated more economic value than traditional data flow. This data flow and transparency contribute to economic development as innovations, knowledge, inventions, talents, and best practices are disseminated globally. As a result of the network of partners, collaboration in real-time, and virtualisation, companies can be horizontally and vertically integrated, thus giving access to real-time information.

Organisations are no longer limited by geographical boundaries and increasingly becoming networked organisations. With the rise of networked individualism and networked sociality, which characterise one of the leading new economy premises, employees independently create a network of connections that can support them to develop and enhance their skills (Rainie \& Wellman, 2018; Wittel, 2001). Employees utilised the diverse social networks and community of practices to get immediate answers to unforeseen circumstances at work (Lampe \& Ellison, 2016; Lee \& Lee, 2020; Tankovska, 2021). The increase of self-employed entrepreneurs and networked individuals impacts almost every industry and human life aspect. For example, the rise in fintech has influenced the traditional financial system with strategies, such as venture capital, online crowdfunding platforms, and project bonds. Banks and government institutions no longer play the sole role in financing projects (Jones, 2017; Khazaei, 2020). The fund required to set up any corporation can be easily generated.

According to Statista (2020), in 2019, global crowdfunding was estimated to be valued at 13.9 billion USD and is expected to triple in 2026. The key fundamental difference between the modern and the traditional economy is the pace at which things are changing. A start-up company can generate the capital needed globally without necessarily having a huge capital to start operating. Companies such as Uber, Facebook, and Alibaba would not have been possible in a traditional economy. Although 
not every company embraces the change, certain existing businesses continue to use twentieth-century operating methods. On the other hand, emerging businesses gain competitive advantages by using technologies to function differently.

\section{Changes in Terms of Job Longevity and Career Path}

For many years, corporate jobs have been a secure path for job security. The traditional job settings have been characterised by their employees' longevity and career path development nature. Individuals look for a lifetime opportunity with a secure career pathway that will guarantee a better job, future, and pension when searching for jobs. However, this scenario is changing. Recent studies have shown that the younger generation finds higher security in entrepreneurship than corporate works (Kane, 2015). The former is perceived to be more secure than the traditional career path. Additionally, to retain these workers, organisations must create a lifelong learning culture by providing resources that support training, self-development and mentorship programmes, and a flexible workspace (flexible schedules, remote work possibilities) (Benson, 2016). Furthermore, one of the main characteristics of the current workforce is the increasing diversity which includes race, ethnicity, gender, sexual orientation, and religion.

The report by Deloitte (Parmelee, 2020) revealed that an inclusive and diverse workplace increase job loyalty among millennials. Corporations are responding to the changing workforce by implementing diverse work programmes such as contingent jobs, remote offices, and the recognition of a multigenerational workforce (Scully-Russ \& Torraco, 2020). In terms of skill sets, modern professionals are dynamic and possess cross-functional and cross-dimensional skills sets. Consequently, corporations must adapt to the diverse changing need of their customers to be at the competitive edge. Modern organisations are customer-centric. Thus, the focus of organisations is more on meeting customers' demands. Since these demands are very dynamic, the organisation must reinvent itself by developing integrated strategies to meet them (Ceesay, 2020).

\section{Changes in the Nature of Work}

Virtualisation has enabled new opportunities for a diverse workforce. Virtualisation provides the possibility for corporations to redefine their talent pool strategy and recruit from anywhere and everywhere. On the organisational structure, corporations are increasingly moving from a rigid hierarchical structure into a more agile or organic structure with cross-functional teams that can quickly and reflexively respond to change. Modern organisations are characterised by a lifelong learning culture and continuous shift towards a cross-functional and project-based team. For example, in the Spotify Agile Model of squads, tribes, and guilds, employees are organised into nine-person 'squads' under the leadership of Tribes instead of organising teams into departments. This approach is increasingly being adopted in many organisations such as ING HQ, NETFLIX, and Signify (Bughin et al., 2018; Mankins \& Garton, 2017; McKinsey, 2017; Perkin, 2017). 
The decentralised horizontal network of competence enables organisations to quickly respond to the current market demands (Denning, 2021). Developing these competencies often occurs naturally via learning from one individual to another, subsequently institutionalising at the organisational level (Crossan et al., 1999). Tsoukas (2009) suggested that knowledge is created in the dialogical viewport when individuals make 'distinction' at a given task. This new distinction coupled with individuals' experiences may lead to further knowledge that later develops when employees engage in dialogical exchanges. As a result of this dialogue, employees may distance themselves from their customary and reflective way of working, leading to new knowledge made possible through three change processes (conceptual combination, conceptual expansion and conceptual reframing). These processes involve social, cognitive, and psychological processes (Crossan et al., 2011).

\section{Changes in the Demands of Workforce Skills}

As a result of the various organisational changes, the required skills, knowledge, and competencies have changed. In the 1980s, quality was the primary management tool for improvement. Thanks to the complete quality and continuous improvement trend, many businesses could adapt to developing challenges. In the 1990s, the attention shifted to business progress reengineering. Several companies adopted this strategy to streamline processes and reduce costs. Simultaneously, corporations shifted beyond cost reduction into incorporating information technology (ICT) as means for efficient and better ways of undertaking business (Tapscott, 1996). The emphasis was on technology as a means to increase productivity, but less attention was placed on human factors (Grover et al., 1998). The new economy is being welcomed as an era spearheaded by human intelligence, providing rise to new kinds of works and rising demand for specialised knowledge work. 'Cognitive technologies'(Schatsky et al., 2015) and human capital are at the forefront.

In a traditional environment, work is designed to solve anticipated problems from different directions that could be imagined, and training are designed to meet these anticipated problems. The approach has changed from ready and pre-prepared reactions and behaviours towards more intellectual work in the new economy. Workers have to act autonomously, individually responsible for first perceiving the situation, analysing it, finding solutions and subsequently capable of choosing the right and appropriate solution to solve this problem. Hence, the increasing demands of competencies in analysing situations, making sense of the situations, having the ability to approach a problem and being capable of deriving solutions critically is crucial for the present generation of workers. Previously, most automated tasks were manual, but now both manual and knowledge work can be automated (Frey \& Osborne, 2017). With the advancement in technology, computers are capable of completing tasks that most humans could do (Cichocki \& Kuleshov, 2021; Scully-Russ \& Torraco, 2020). Mckinsey's report (Manyika et al., 2013) estimated that 110 to 140 million full-time knowledge work could be automated.

The emergence of new types of jobs and the notion of green technology and economy also spur the increasing demand for new types of products and skills sets 
(Khazaei, 2019a, b; Kochhar, 2020). Therefore, human capital is becoming the main asset and core of modern organisations' competitive advantage. The main challenge is how organisations can develop these core competencies. Researchers and institutions such as the World Bank, International Labour Organisation (ILO), European Union (EU) commission, and McKinsey Global Institute (MGI) have undertaken several studies on future skills. Van Laar et al. (2017) carried out an extensive literature review on twenty-first century and digital skills. They identified seven core skills that drive competitive advantage in modern organisations: technical, information management, communication, collaboration, creativity, critical thinking, and problem-solving. Five contextual skills were also discovered: ethical awareness, cultural awareness, flexibility, self-direction, and lifelong learning.

In addition, other skills such as analytical thinking, emotional intelligence, service orientation, system analysis, troubleshooting and user experiences, persuasion and negotiation, leadership, and social influence are mentioned in the World Economic Forum (WEF) Future of Job 2020 report (WEFORUM, 2020) as top emergence skills that are continuously in demand. According to Van Laar et al. (2017), in contrast to digital skills, twenty-first-century skills are not necessarily underpinned by information technology. The reports by WeForum (Whiting, 2020) mentioned problem-solving and critical thinking as the top list of skills organisations believe will be highly needed in the future. Another recent study by Mintullabo et al. (2019) highlighted skills capable of handling and managing change, including problemsolving, self-regulation, ability to learn, development, and management of personal competence and skills related to digitisation, which will be highly needed. Bughin et al. (2018) predicted an increase in the demand for higher cognitive skills (creativity, critical thinking, others), soft skills (emotional and social, learning, negotiation, others), and technological skills (data analysis, programming others). They further added that the demand for basic cognitive skills such as basic literacy and data input would decline. In contrast, the needed higher cognitive skills will continue to grow through 2030 .

\section{The Economic Perspective of Change}

Economists have tried to explain the dynamism and challenges involved in the economy using institutional dynamism. Several views exist, such as the historical, evolutionary and intentionally created perspectives (Greif, 2006a). According to the evolutional perspective, individuals possess specific characteristics that dictate their behaviour. Economic institutions are seen as patterns of behaviours resulting from the unintentional consequences of human interactions. Changes in the economy are due to mutation, and these interactions, over time, determine the success of any institution. This view believes that endogenous elements cause organisational changes, and the forces that drive these changes are endogenous.

The historical process view believes that the current environmental change results from subsequent historical events. For example, the past social network is the foundation of the current institution. Organisations that inherited previous knowledge assets such as routines, know-how, and capacity can use these assets to scale up to 
a new high height, thus, the asymmetry between the current and previous organisations. Past organisational cognitive models influence the current organisations. This view supports the deterministic theory of history and views social factors as the central analysis for change. According to Greif (2006a), past influences caused organisations to evolve in diverse trajectories. The intentionally created view is that changes in the economy are caused by individuals who are 'forward thinkers', and the current environmental change is not restricted by history. The intentionally created view emphasises the induction view of the environment and postulates that a new institution reflects the current view of economic agents. These views see change as an exogenous element caused by decision markers (Greif, 2006b).

The modern economy is an important term that has been characterised and analysed in several different fields, such as economics and anthropology in social science in terms of intangible assets, including labour which is viewed as a property of the classic era. Many corporations, such as IBM, have witnessed the shift in their value creation stream from leasing tangibles assets to complete knowledge or intangible assets (Jemielniak, 2012a). Other sectors, such as the gaming industry, has witnessed a complete rebirth, moving from arcade to cloud or virtual reality services (Wallach, 2020) and others. Bhasin et al. (2021) argued that the modern economy has seen a decline in physical capital investment as firms develop a disintegrated vertical strategy that emphasises profit accumulation and a lower marginal propensity to invest. They battle for labour cost reduction in favour of a smaller workforce that is knowledge-intensive and a reduction in the cost or investment for capital goods.

In the twentieth century or Fordist era, companies were known for their large number of workers who work at the production factor (Prahalad \& Hamel, 1990). Nevertheless, the situation has changed as the modern economy organisations focus on core competency by outsourcing labour to freelancers, cheaper countries, or other organisations. As the battle for labour reduction and profit accumulation increases, employees are often overworked, which is why the work-life balance concept has become famous (Nocks, 2021; Weil, 2014). Organisations have moved from having many manual workers in production processes to fewer workers with more tacit knowledge.

\section{Theoretical Framework}

According to Knowledge-Based View theory, knowledge has a life cycle based on its application within an organisation or surrounding environment as professional knowledge (Fu-Sheng et al., 2017). The literature highlights the implementation of knowledge management practices to provide employees with the skills necessary for developing and applying information (Fu-Sheng et al., 2017) (refer to Fig. 1).

The theory of human capital asserts that an organisation's role is to safeguard and maintain the standards of its core competencies by investment in continuous learning and development programmes (Wuttaphan, 2017). Human capital theorists claim that the concept of knowledge and its management can be defined in terms of intellectual capital and that people's capacity to learn is on par with other production 


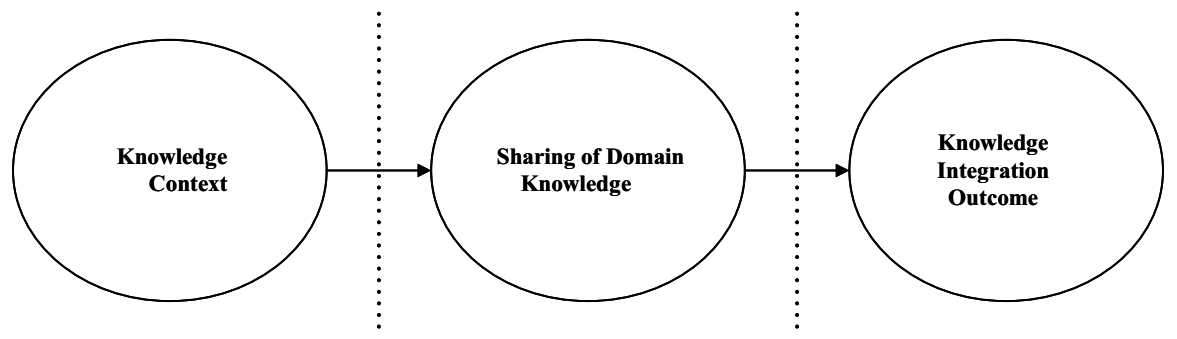

Fig. 1 Relevant principles of knowledge-based theory

inputs (Wuttaphan, 2017). According to this theory, the motivation for employees to enhance their abilities stems from a desire to boost output. Thus, the greater the variance in skill(s) between employees, the greater their worth to the organisation. They supply the organisation with a unique set of skills that competitors cannot duplicate (Wuttaphan, 2017). Additionally, a firm's economic advantage is determined by its employees' abilities and expertise (Refer to Fig. 2).

Employees are only valuable to an organisation if they meet four criteria. First, the skills must be valuable to the extent that they positively impact the production process through increased quantity and quality to sustain the customer base. Second, the uniqueness of the skills possessed by employees must increase within a given environment and third, any other investment cannot match the overall value of the human capital investment. Therefore, following the impact of recent fundamental economic and technology-based activities, the study objectives focused on managing KWrs' core competencies within a knowledge culture and supporting structures, such as communities of practice, knowledge mapping, and overcoming the challenges of fast-growing technologies.

Following the knowledge-based view theory and the theory of human capital, this study seeks to propose practices that bring value to the organisations by increasing the abilities of KWrs, which results in improved institutional performance. Moreover, modern companies' sustainability is contingent on their willingness to invest in their KWrs as sources of desirable organisational performance (Atapattu, 2018). In a knowledge economy, value is added by the natural abilities and skills of the workforce acting within appropriate organisational structures, practices, and regulations, referred to as intellectual or knowledge capital

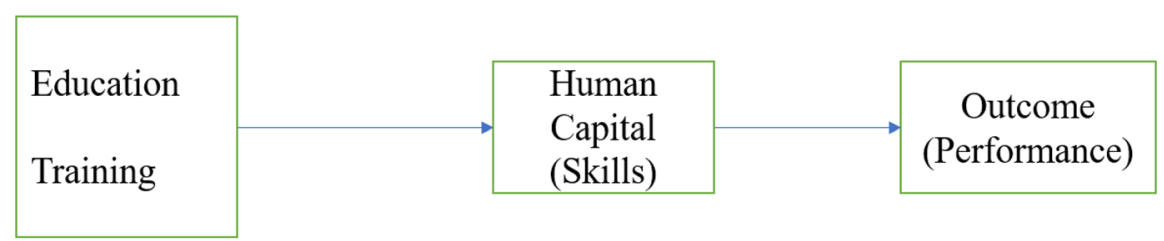

Fig. 2 Human capital perspective 
(Fu-Sheng et al., 2017). Unlike organisational knowledge, the difficulty in managing this capital is that the firm has no control over it. Thus, knowledge management is a critical contributor to the human performance that has garnered considerable attention as a critical strategic issue in many businesses.

This study focuses on organisations' internal knowledge usage upon the emergence of new technologies. Therefore, this study contributes to the literature by extending the knowledge-based perspective and human capital theory that emphasises the most effective skills for KWrs as considerable firm resources in the recent era. This notion can be justified by the fact that certain critical choices involving knowledge management must be taken to address the competency gap. Additionally, this study proposes that the decisions will be effective only if the management system promotes specific vital competencies.

\section{Methods}

An expert panel research method has been used to gather data related to the required skills and competencies of KWrs. The expert panel is a highly appropriate exploratory research method when dealing with diverse perspectives that require specialised input, recommendations, and foresight (Bakule et al., 2016; Popper, 2008). Diverse cognitive and subjective opinions exist when assessing competencies. Varying competencies approaches exist, and organisations differ in how competency is viewed or utilised.

Planning activities such as recruiting or retaining the KWrs can be viewed as a complex decision problem. Various types of expertise and subjective assessments might be used to evaluate the decision alternative against a large number of potentially conflicting criteria. Expert panel analysis is a technique for resolving impasses in decision-making. The method aims to simulate the decision maker's subjective judgments. Distinguishing between decision goals and attributes and the uncertainties associated with the state of the nature and outcomes of decisions during decision analysis is critical. In other words, situational facts, uncertainties, and associated values are identified (Bakule et al., 2016). Expert panels should include a decision-maker, project leaders, technical experts, and normative expert(s) to ensure a sound decision-making basis. The participants' roles vary according to the nature of the case and the available resources for discussion and additional work. The expert panel process is as follows:

(1) Problem structuring

(2) Development of appropriate formats for identifying the context for expert judgments, associated uncertainties and rationale for argumentation

(3) Panel session preparation

(4) Panel session(s)

(5) Reporting the results 
The panels' expertise may come from various disciplines depending on the scope and nature of the issue. The experts organise the analysis work, propose decision possibilities, and summarise the case for the investigator. The researcher or decisionmaker is responsible for compiling existing analyses and other pertinent information (Bakule et al., 2016). In general, the expert panel process may be initiated immediately upon encountering a decision-making situation. First, the experts who will participate in the process are chosen. Next, their analysis tasks are defined per situational requirements. Nevertheless, initiating the expert panel process after conducting preliminary analyses and discussing their preliminary findings is more natural.

If additional analyses or checks are identified during the panel session, tasks are assigned to responsible experts, and a new panel session is scheduled after obtaining the additional information (Bakule et al., 2016). The analyses conducted to resolve the issue are briefly discussed, and pertinent information is distributed to the participants. The second stage of the expert panel procedure is primarily composed of normative experts. The purpose of this task is to identify core competencies among KWrs based on the panel's experience and to document the technical experts' perspectives and findings.

Therefore, this method has been used as it offers the advantages of collecting and synthesising diverse specialised opinions. A drawback of this method is that the experts may be wrong, or their opinions do not necessarily reflect reality. The survey was conducted from the 31 May 2021 to the 14 June 2021. Experts are highly experienced professionals and researchers in the domain of professional services, manufacturing, and other related fields strongly connected to knowledge work. Some of them are authors, theorists, policymakers, and influencers in their fields. The views of experts were noted without any modification that will change the context. Similar views were grouped or excluded to avoid repetitions. Table 1 shows the countries where the data was collected.

Table 1 The geographical coverage of the study

\begin{tabular}{llc}
\hline Location & $\begin{array}{l}\text { No. of } \\
\text { respondents }\end{array}$ & \% of respondents \\
\hline China & 1 & 4.76 \\
Denmark & 1 & 4.76 \\
France & 2 & 9.52 \\
Germany & 1 & 4.76 \\
Netherlands & 2 & 9.52 \\
Poland & 3 & 14.29 \\
Spain & 1 & 4.76 \\
Switzerland & 1 & 4.76 \\
Togo & 1 & 4.76 \\
United Arab Emirates & 1 & 4.76 \\
United Kingdom & 2 & 9.52 \\
United States of America (USA) & 4 & 23.81 \\
Grand total & $\mathbf{2 0}$ & $\mathbf{1 0 0 . 0 0}$ \\
\hline
\end{tabular}




\section{Criteria for Selection}

The following criteria were used for the selection of experts:

1. Well recognised experts or researchers or scientists in their field

2. Have leadership background

3. Have experience in managing or building workplace relationships

4. Have at least 10 years of work experience in organisations

5. Come from selected sectors (education, professional services, manufacturing, ICT, others)

All the experts have worked with top multinational organisations and were believed to possess knowledge of existing workforce trends, derive skill requirements, and spot trends in the global market. Hence, the selection criteria were set to delimit selection and target experts from this category. A total of 30 experts were contacted via email and LinkedIn to participate in the survey. Twenty experts agreed to participate and gave their views. Of the 20 experts, $65 \%$ (13) were male, while $35 \%$ (7) were female. Regarding their experience in a supervision role, $75 \%$ have more than 10 years experience in a supervision role, $10 \%$ were experienced between 6 to 10 years, whereas $15 \%$ were between 1 and 5 years. In terms of domains of economic activity, the experts had the choice to choose more than one domain of economic activity where applicable. They were from professional services (50\%), scientific/education (10\%), ICT (50\%), manufacturing (10\%), and others (5\%). The education level of the experts showed that $20 \%$ indicated that they have a $\mathrm{PhD} / \mathrm{PostDoc}, 45 \%$ had a master's degree, and $35 \%$ had a bachelor's degree.

\section{Participants}

\section{Questionnaires}

The questionnaire was framed with a set of open-ended questions, which offered the possibility to gain a wide range of perspectives on the issue. The table below lists the questions and the objectives (Fig. 3) (Table 2).

\section{Results}

In order to gain a comprehensive response to the required competencies of KWrs, how they can be achieved, and other challenges, the questions regarding competencies were grouped into five categories: physical and manual skills, basic cognitive skills, higher cognitive skills, social and emotional skills, and technological skills. Each category has a set of skills based on the MGI's workforce skills 

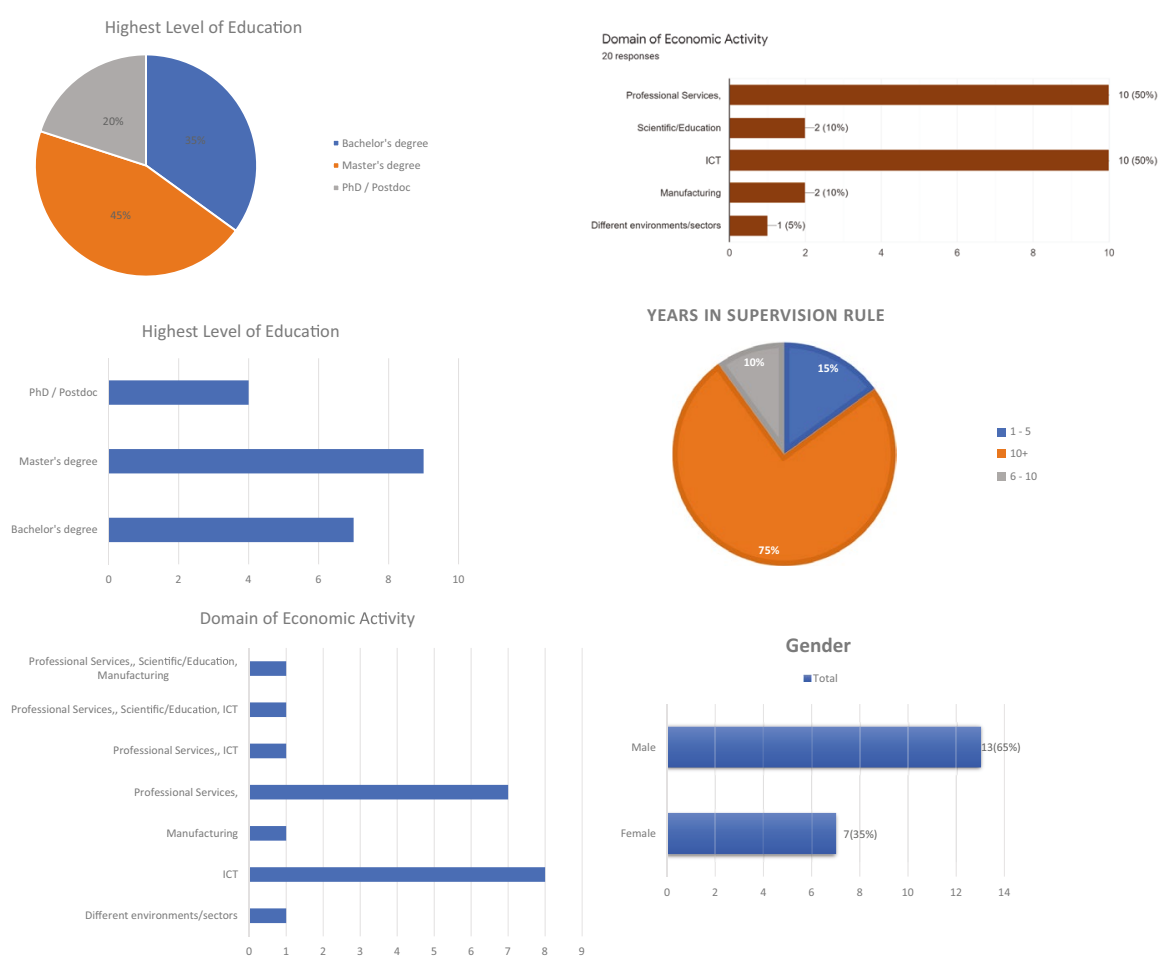

Fig. 3 Gender, education level, years in supervision role, and economic activity domain chart

model, as described in Bughin et al. (2018). The table below shows the number of respondents and the percentage for each skill category (Fig. 4) (Table 3).

The experts were asked to provide additional comments on skills that were not mentioned and significantly necessary. The following competencies were noted:

- People and businesses value

- The ability to know what is current and what is expected

- Understanding business processes and any legal or tax, or financial knowledge

- Double listening, mindfulness

- Design thinking and sense-making

- Cross-disciplinary mindset, ability to connect ideas and thoughts across many disciplines (being generalist)

- Boldness and patience

By analysing the result, the highest-rated skills were inspecting and monitoring skills, critical thinking and decision making, interpersonal skills, and empathy, whereas the lowest with $20 \%$ was gross motor skills and strength. The Pareto analysis revealed the most needed aspect of skills and the aspects that should be emphasised (Fig. 5). 


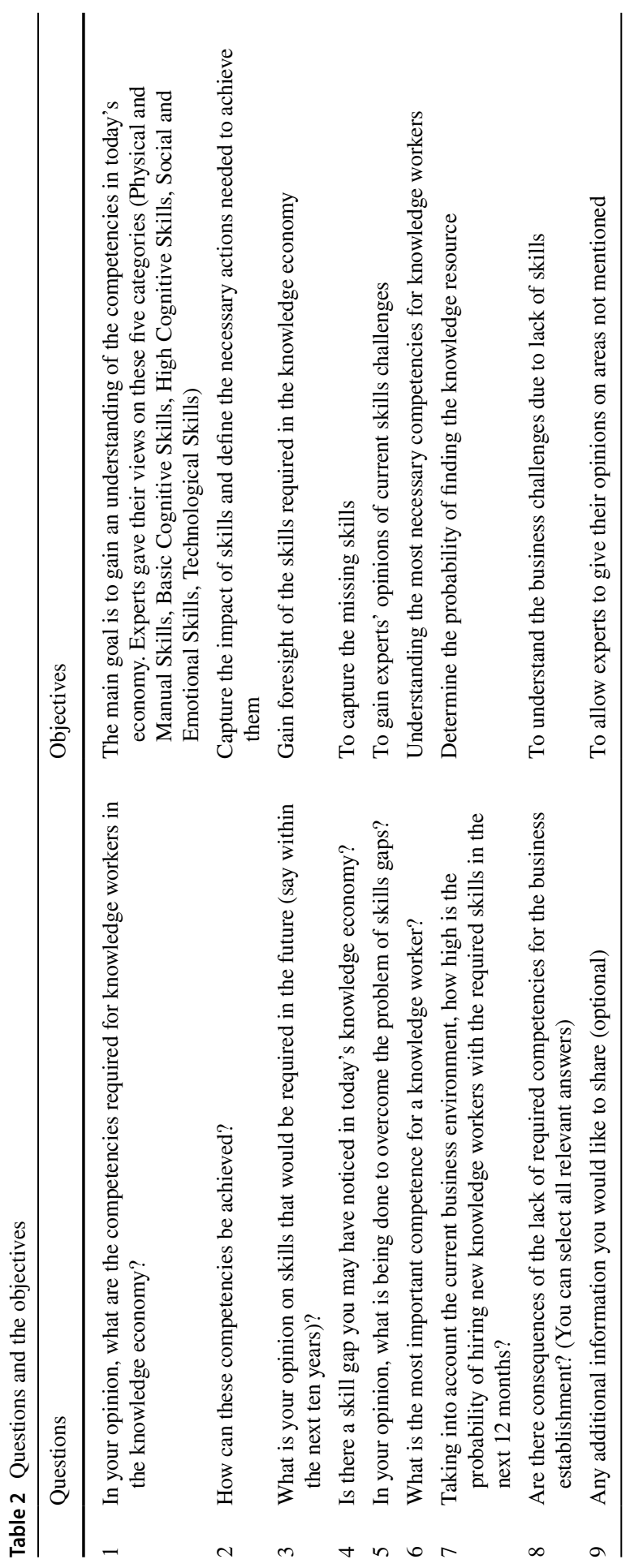




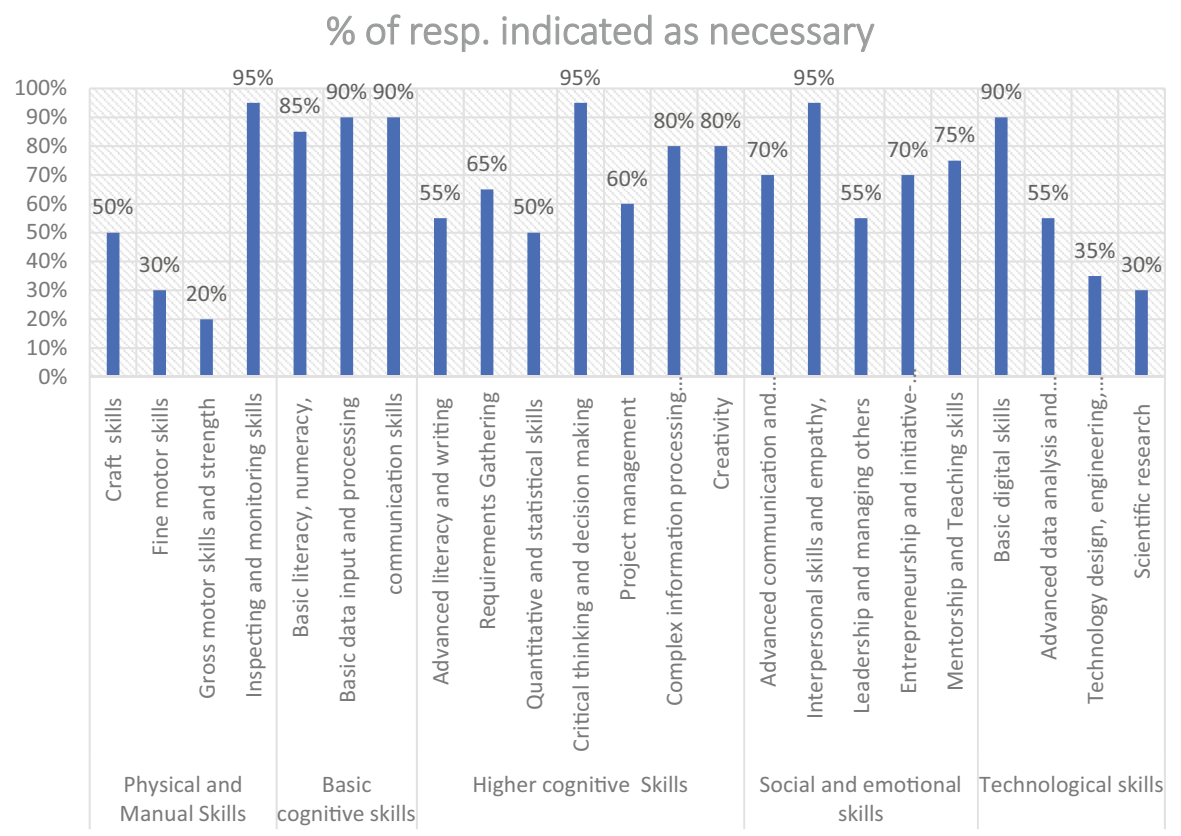

Fig. 4 Percentage of response per each skillset

\section{Ways to Achieve Required Skills}

The respondents' answers are qualitative data. Thus, the texts were only edited for minor grammatical and punctuation errors. All 20 experts gave opinions on how necessary skills can be acquired, synthesising similar responses. The following ways of acquiring the necessary competencies were noted:

- Training and On the Job - Continuous Learning: The will and drive to keep learning

- Reflection - Through experience, Training, or More Informal Ways. Taking short courses, practice, and good mentorship

- Teams - Engage the Best Persons from Teams. The necessary skills can be gained through experiences and social learning with others that involve collaborating and cocreation

- Have someone in each department be the conduit for the KWr to understand the problems in each department

- Allow people to make mistakes and give them the time to correct and learn from them. Make sure information is gathered to overcome mistakes from happening twice. Have the ability to not work inside boxes but integrate

- Diversification of Area Knowledge: general knowledge could be more needed than specification

- Technology: Understanding the technology and practical experience or application

- Formal Education: Go to universities that do not follow trends but give you a solid background and help you to think and not to follow. Through experiential learning 
Table 3 Skills category and the number of respondents

\begin{tabular}{|c|c|c|c|}
\hline Category & Skills/Competences & $\begin{array}{l}\text { No. of resp. } \\
\text { indicated as } \\
\text { necessary }\end{array}$ & $\begin{array}{l}\% \text { of resp. } \\
\text { indicated as } \\
\text { necessary }\end{array}$ \\
\hline \multirow[t]{4}{*}{ Physical and manual skills } & Craft skills & 10 & 50 \\
\hline & Fine motor skills & 6 & 30 \\
\hline & Gross motor skills and strength & 4 & 20 \\
\hline & Inspecting and monitoring skills & 19 & 95 \\
\hline \multirow[t]{3}{*}{ Basic cognitive skills } & Basic literacy, numeracy, & 17 & 85 \\
\hline & Basic data input and processing & 18 & 90 \\
\hline & communication skills & 18 & 90 \\
\hline \multirow[t]{7}{*}{ Higher cognitive skills } & Advanced literacy and writing & 11 & 55 \\
\hline & Requirement gathering & 13 & 65 \\
\hline & Quantitative and statistical skills & 10 & 50 \\
\hline & Critical thinking and decision making & 19 & 95 \\
\hline & Project management & 12 & 60 \\
\hline & $\begin{array}{l}\text { Complex information processing and } \\
\text { interpretation }\end{array}$ & 16 & 80 \\
\hline & Creativity & 16 & 80 \\
\hline \multirow[t]{5}{*}{ Social and emotional skills } & $\begin{array}{l}\text { Advanced communication and } \\
\text { negotiation skills }\end{array}$ & 14 & 70 \\
\hline & Interpersonal skills and empathy, & 19 & 95 \\
\hline & Leadership and managing others & 11 & 55 \\
\hline & Entrepreneurship and initiative-taking & 14 & 70 \\
\hline & Mentorship and teaching skills & 15 & 75 \\
\hline \multirow[t]{4}{*}{ Technological skills } & Basic digital skills & 18 & 90 \\
\hline & $\begin{array}{l}\text { Advanced data analysis and } \\
\text { mathematical skills }\end{array}$ & 11 & 55 \\
\hline & $\begin{array}{l}\text { Technology design, engineering, and } \\
\text { maintenance }\end{array}$ & 7 & 35 \\
\hline & Scientific research & 6 & 30 \\
\hline
\end{tabular}

- Education is the key, but not just the formal sense. We still need to keep everyone informed, whilst people do not understand the risks and how to use knowledge safely. Government has a role to play, especially in local government where trust may be higher. Community groups are also key to supporting people

\section{The Skills and Competencies that will be Required in the Future}

All experts responded to this question, and below is the synthesised response from the respondents:

- The ability to learn and adapt is essential. However, most important is the capability to have critical thinking, reasonable doubt and see above and beyond periodical trends. Hyper specialisation is a risk. The ability to be structured, 


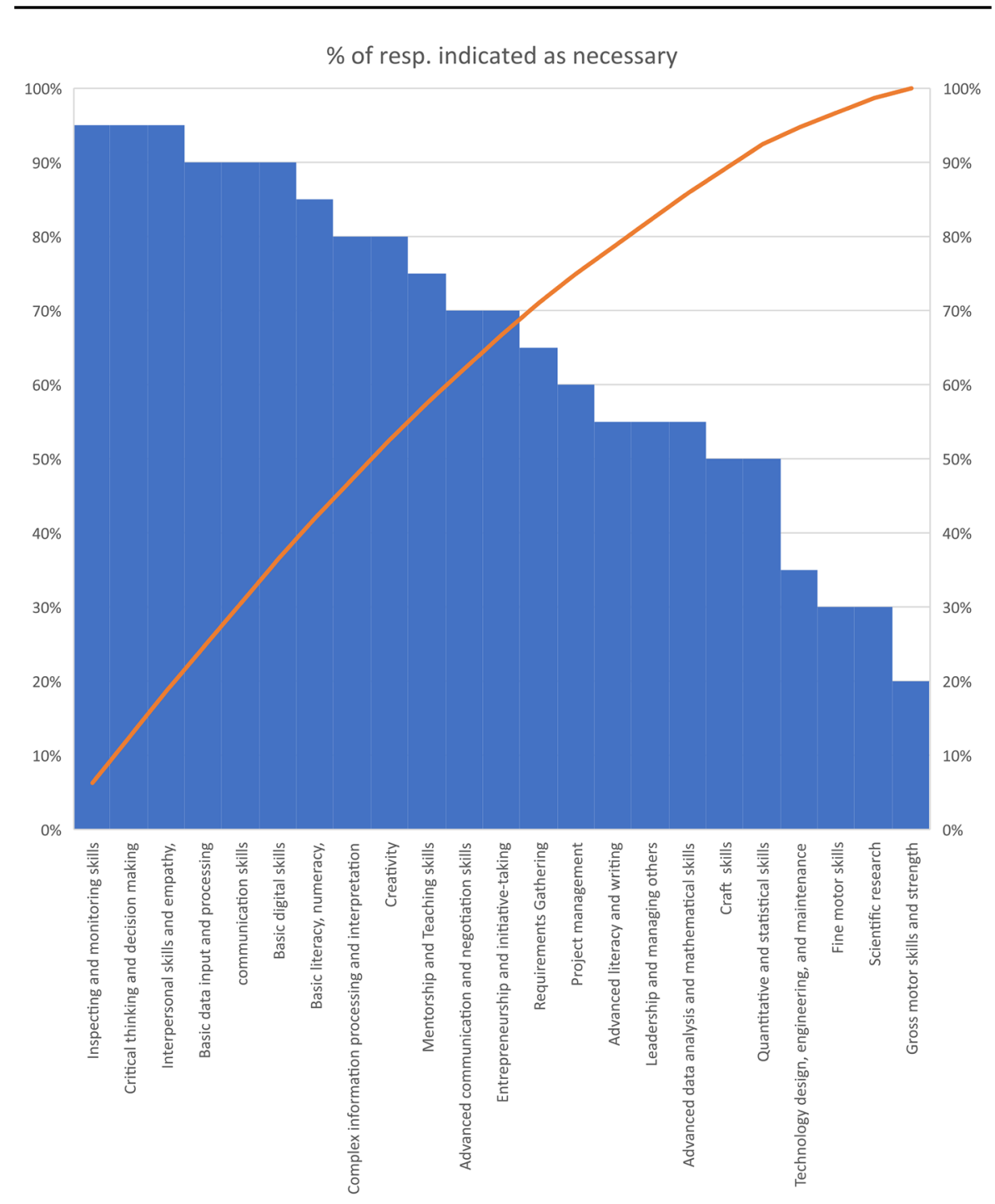

Fig. 5 Pareto chart of all respondents

organised, and have a solid and confident personality will help you always in being a KWr. The trends are trends that last some years.

- Problem-solving is a very important aspect of knowledge management. The KWrs should be able to support problem-solving.

- Mostly programming skills, but I think most people will be stuck in service industry. Artificial intelligence variations, applying artificial intelligence, and machine learning.

- Ability to Search for Information. It is a combination of IT helping the AI robots but also people learning to ask questions and search for keywords. There also 
needs to be knowledge of computer security to avoid being 'cheated' out of information. Curious people look beyond the first page and question and check the information. These skills need to be developed in an open society. In a more closed society, the government will step in, but that can be too restrictive and reduce thought by the seeker of knowledge.

- Ability to understand the complete process flow.

- Working together as a collective entity to get the best results.

- Human behaviour and soft skills, especially curiosity, creativity, adaptability, arts and craft, and intuition.

- Product management.

- Basic and non-academic skills will be more required for improved job performance in the future.

\section{Challenges and Skills Gap in Today's Knowledge Economy}

Among the 20 experts, $80 \%$ (16) agreed that they had observed skills gaps. In order to describe the challenges in modern organisations, one of the experts noted that 'After working for 37 years as an IT knowledge worker within a global company, supporting different business processes, I saw several waves regarding the place in the organisation of the IT knowledge worker, going from within the business organisation, to the IT organisation, from there to outsource to low-wage countries. This is because it has to be cheaper and cheaper, but with a loss of knowledge as a result. The biggest challenge is therefore to find ways to secure company knowledge'. The expert invoked the issue of how knowledge can be retained. Below are the mentioned skills that are lacking and challenges as indicated by experts.

- The ability to go above and beyond the current trends. The ability to stop and think, pause and learn. Curiosity: the ability to 'ask why' and investigate further

- The will to look further than the boundaries

- Critical thinking

- Lack of understanding of the business processes

- More time devoted to training should be a priority in the companies

- Filtering fake news and pseudo-know-how

- Higher cognitive skills: project economy and sustainability concepts

- People and business value... and common sense

- Digital literacy, communications, social intelligence

- Ability to understand cultural differences

- People have become too specialised. Broad knowledge is critical to creativity and innovation (hybridising the is ideas across fields)

- The move to online and the use of knowledge as a requirement to live and apply for help has dis-enfranchised many individuals and is leading to a widening wealth gap that does ordinary people a dis-service. Without access to education and technology, there is a challenge to improve the situation. This also restricts the work opportunities of many as they cannot enter a job in the knowledge economy. There is a lot of reliance on self-improvement, and in some companies, 


\section{\%. OF EXPERTS WHO AGREED}

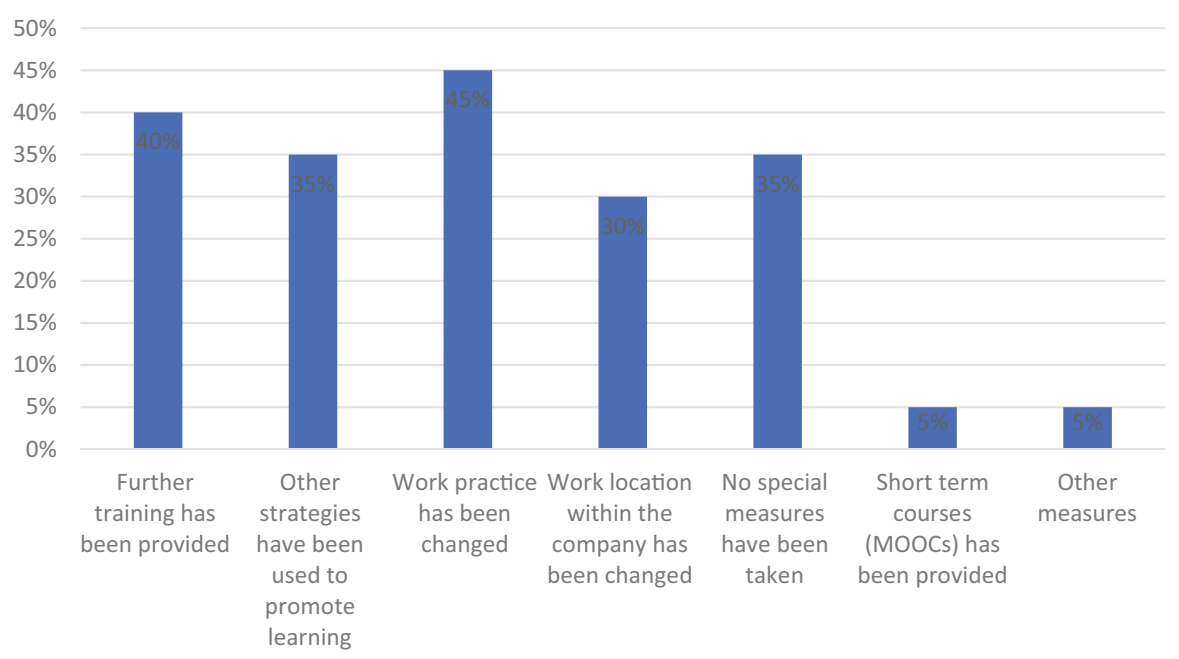

Fig. 6 Percentage of respondents who agreed with the actions taken to overcome the skills gap

the desire to develop people over the long term is not a priority. So, companies need to address the issue but are reluctant as those they have trained can easily leave for better pay.

- It is not knowledge workers, but the knowledge intense industries have declined, particularly education. These knowledge intense industries have forgotten the grassroots of being a knowledge intense industry. They lack sustainability, more so from leadership not understanding the broader context of a knowledge economy.

\section{Measures Taken by Firms to Overcome These Challenges}

Sixteen (80\%) experts agreed that a skill gap exists and indicated that the following actions had been taken to overcome the challenges (Fig. 6) (Table 4).

Table 4 Actions taken were taken to overcome the skills gap

\begin{tabular}{|c|c|c|c|}
\hline Actions taken to overcome skills gap & $\begin{array}{l}\text { No. of experts } \\
\text { who agreed }\end{array}$ & $\begin{array}{l}\text { No. of experts } \\
\text { who agreed }\end{array}$ & $\begin{array}{l}\% \text { of } \\
\text { experts who } \\
\text { agreed }\end{array}$ \\
\hline Further training has been provided & 8 & 19 & 42 \\
\hline Other strategies have been used to promote learning & 7 & 19 & 37 \\
\hline Work practice has been changed & 9 & 19 & 47 \\
\hline Work location within the company has been changed & 6 & 19 & 32 \\
\hline No special measures have been taken & 7 & 19 & 37 \\
\hline Short term courses (MOOCs) has been provided & 1 & 19 & 5 \\
\hline Other measures & 1 & 19 & 5 \\
\hline
\end{tabular}

MOOC massive open online course 


\section{PERCENTAGE OF RESPONDENTS INDICATING THE PROBABILITY LEVEL OF HIRING NEW WORKERS}

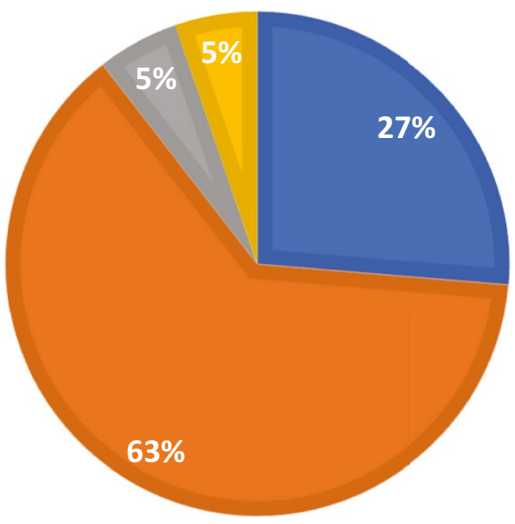

0-15\% low

-15-50\% medium

-50-75\% high

$75-100 \%$ very high

Fig. 7 Percentage of respondents indicating the probability level of hiring new workers

The figure above shows the probability of hiring new KWrs workers with the required skills in the upcoming 12 months. A total of 19 respondents responded, and $63.2 \%$ indicated that the chances are medium (15-50\%), 26.3\% stated low chances, and 5.3\% indicated that the chances are high or very high. Businesses may face some challenges due to the difficulties in hiring (Fig. 7) (Table 5).

\section{Impact to the Business as a Result of Missing Competencies}

Other effects were also indicated:

- Keeping the correct knowledge in house, due to heavy load of work on them

- Safeguard and keep knowledge within the company

- Retention of personnel will drop

- Lower net promoter scores (NPS) scores

- Drop in the ability to innovate (think outside the box)

Table 5 Impact to the business

\begin{tabular}{lll}
\hline Effects on business & $\begin{array}{l}\text { No. of } \\
\text { responses }\end{array}$ & $\%$ \\
\hline Lose business or orders to competitors & 13 & 72 \\
Have difficulties introducing technological change & 13 & 72 \\
Delay developing new products or services & 13 & 72 \\
Experience increased operating costs & 11 & 61 \\
Have difficulties in meeting customer services needs & 14 & 78 \\
Others & 7 & 39 \\
\hline
\end{tabular}


Table 6 Most important competences for a knowledge worker

Most important competences for a knowledge worker

\begin{tabular}{ll} 
Collaboration & Curiosity and a desire to learn \\
The ability to go above and beyond the current trends & Curiosity and Hansei attitude (self-reflection) \\
Ability to learn and gather knowledge & People and business value \\
Critical thinking & Learn-to-learn \\
Understand the process a to z & Connecting people who need each other \\
Openness to learning and deep dive in new technologies & Analysis, logical thinking, basic math \\
Being analytical & Creativity and inclusive social facilitation \\
Listening and understanding their audiences & Analytical thinking and communication \\
Motivation and attitude & Ability to ask questions and Investigate more \\
\hline
\end{tabular}

\section{Key Competencies for Knowledge Workers}

The experts indicated the following competencies as essential for a KWrs in a modern economy (Table 6).

\section{Discussion}

The primary study objectives aimed to understand the competencies of KWrs in the modern economy, how these competencies can be achieved, understanding the challenges, and measures used to overcome them. Subsequently, the competencies were grouped into five categories: physical and manual skills, basic cognitive skills, higher cognitive skills, social and emotional skills, and technological skills based on the MGI's workforce skills model. Bughin et al. (2018) provided a clearer view of how the result fit or responded to the objectives. The frequently mentioned competencies are grouped under these categories, and other uniquely uncategorised competencies are also mentioned.

\section{Physical and Manual Skills}

Gross motor skills (20\%) and fine motor skills (30\%) were the lowest-rated skills among the required skills for KWrs. The activities of KWrs are viewed as tasks that require high cognitive competencies. As a result, manual and physical skills have been significantly underlooked or almost not mentioned in the literature when referring to knowledge works. Although some motor skills may be required in some knowledge work (Jemielniak, 2012b), the skills do not constitute a significant aspect of the required competencies. These findings support the general view of KWrs (Davenport, 2005; Ehin, 2008; Pont, 2001). Nevertheless, more than 50\% of experts indicated that inspecting and monitoring skills (95\%) and craft skills (50\%) are vital for KWrs in the modern economy. Craftwork that involves a high level of intellectual work can be considered knowledge work since it involves knowledge and highly embedded skills to create new art that is often unique and difficult to imitate.

According to De Munck (2019), artisans' creation of new products in medieval times is almost similar to today's product creation. De Munck (2019) argued that 
craftwork forms the basis of the 'scientific revolution'. Regular dealing by artisans, artists, and specialists with problems facilitated the transition from speculative (deductive) reasonings to inductive knowledge grounded in observation and experimentation, which is not limited to the invention of new products or technology but in creating new ways of doing things. He stipulated that according to history, science artists constantly train their mental faculty through discernment and their daily operations, which require some attention to detail. In manufacturing craft, producing a new product involves not only the hands but the craftsman's expertise and fusion of intuition and spirit. As a result of perfecting their task, they also look at the ethical aspect of their work. The growing demands for designs and arts, whether in digital or physical format (in presentation or graphic design), show how essential craft skills is a vital requirement that a KWr must possess in the modern economy.

\section{Basic Cognitive Skills}

At least $85 \%$ of experts indicated that basic cognitive skills are required skills for KWrs. For the question on skills required in the future, one of the experts noted that 'basic and non-academic skills will be more required for improved job performance in the future', and another mentioned 'The ability to search for information'. In the modern economy, communication mainly takes place via digital mediums. Organisations communicate and interact with each other via various digital platforms. The Pew Report revealed that about $96 \%$ of employees use communication technologies (Madden \& Jones, 2008). Therefore, skills such as basic data input, ability to plan, data entry in Excel or PowerPoint, basic knowledge of legal requirements, ability to surf the net to search for solutions to problems, and the ability to prioritise are necessary skills that a KWr must-have in the twenty-first century. The working environment is very dynamic. Therefore, possessing multiple, cross-functional, and crossdisciplinary competencies is necessary.

\section{Higher Cognitive Skills}

This category was indicated by more than $55 \%$ of experts as a required competence for KWrs. Critical thinking and decision making (95\%), complex information processing and interpretation (80\%), and creativity (80\%) were among the top mentioned skills. Competence is required as KWrs are responsible for knowledge creation and improving innovation (Horibe, 1999; Maruta, 2012). Modern organisations focus on meeting customers' demands and reacting based on the customers' needs (Ceesay, 2020). Customer centricity forms the basis of modern organisations. Knowledge work involves gathering the customer's requirements and being able to design processes or solutions to meet these requirements. What makes them unique is the intellectual work they do, which requires a high level of cognitive competencies. These competencies enable KWrs to respond to the business' needs. The KWrs are an element of the organisational core competencies. They embodied the organisational core competencies and can use these competencies across organisational 
boundaries (Prahalad \& Hamel, 1990). Besides, the KWr design business processes and must have the competencies to solve problems, design solutions, collect ideas, analyse data, and take decisions. They constantly improve their knowledge to carry out their activities and solve work-related issues successfully. Resultantly, critical thinking, analytical skills, and a high level of creativity are fundamental attributes of a KWr (De Sordi et al., 2021). The type of work they undertake is mostly projectbased work, and a need exists for the ability to manage projects and deliver new products or services within the time, scope, and budgets (Małachowski, 2011).

\section{Social and Emotional Skills}

The social and emotional competencies of a KWr comprise skills such as emotional intelligence, advanced communication and negotiations skills, leadership skills, entrepreneurial skills, ability to collaborate and network, adaptability and continuous learning, mentorship, and teaching skills. More than $55 \%$ of experts indicated that this category is vital for a $\mathrm{KWr}$ (advanced communication and negotiation skills (70\%), interpersonal skills and empathy (95\%), leadership and managing others (55\%), entrepreneurship, and initiative-taking (70\%), and mentorship and teaching skills (75\%)). The KWrs are autonomous workers who perform interconnected tasks (Väänänen et al., 2020). In order to be successful in performing their daily activities, the KWrs must possess strong social and emotional competencies. Emotion intelligence competence consists of the KWr's ability to be self-aware, self-driven, self-motivated, and efficiently manage its relationship to succeed at work (Goleman, 2011). This competence determines the KWr's learning potential at the workplace or self-mastery of on-the-job training, which subsequently translates into organisational success. When one is emotionally upset, the individuals' ability to learn and take a positive decision at work is imped.

Conversely, when one is positively motivated, the individual's actions and decisions become positively driven ceteris paribus. An example could be a KWr who has high education level and high cognitive skills but do not possess an underlying solid emotional intelligence is likely to be unsuccessful at work. Other social and emotional competencies mentioned by experts include double mindfulness, sense-making, situational adaptive, customer service, empathy, team building, collaboration, networked, people, and business value. Developing such emotional competencies requires a firm with underlying emotional intelligence (Goleman, 2011). Emotional intelligence enables the KWr's knowledge creation process via self-awareness and to share knowledge that positively impacts interpersonal relations and job satisfaction (Armstrong \& Taylor, 2017, p.128; Rechberg, 2020). According to Goleman (2011), the KWrs who rank as 'star performers' have higher emotional intelligence. In addition, Goleman (2011) indicated that emotional intelligence plays an essential role at the firm's highest level compared with other competencies, such as high cognitive skills.

Leadership traits were rated by $55 \%$ of experts as required. This competence enables KWrs to independently take decisions that pose a sense of responsibility and a certain level of commitment to the common goal. Goleman (2011) posited that 
emotional intelligence plays a greater role in the leadership style of an organisation or individual, which in turn affects the organisational climate and the leader's success (Tareq et al., 2017). For example, in a coaching leadership style, an executive who coaches instead of scolding his collaborators creates an effective work environment that aims at personal development rather than an immediate work-related task. The leadership style of a KWr can enhance engagement and promotes the creative ability of the team (Chen et al., 2020; Gumusluoglu \& Ilsev, 2009; Wadei et al., 2021). Edelbroek et al. (2019) studied the relationship between transactional and transformative leadership and revealed that transformational leadership competencies positively affect innovation and engagement enhanced by creativity. Multiples studies have shown that enhancing employees' creativity leads to higher innovative competencies among workers (Chen et al., 2020; De Jong et al., 2018; Goleman, 2011; Dubina et al., 2012).

\section{Technological Skills}

Basic digital skills were among the top-rated skills with 90\%, whereas other technological skills were advanced data analysis and mathematical skills (55\%), technology design, engineering, maintenance (35\%), and scientific research $(30 \%)$. The findings confirm Van Laar et al. (2017) and van Laar et al. (2020), which indicated that twenty-first-century skills are not necessarily underpinned by information technology. The literature on knowledge works reveals that technological skills are essential but not necessarily the principal requirement for KWrs, although having basic digital skills is an inevitable competence that a KWr must possess. The KWrs are known for the intellectual value that they bring to the organisation (Horibe, 1999).

Overall, the experts revealed the challenges in getting these competencies where $80 \%$ indicated that the skills gap exists in today's modern economy. In comparison, $63.2 \%$ confirmed that the possibility of hiring new $\mathrm{KWr}$ with the right sets of skills within a year is medium (15-50\%), hence posing some challenges to the business. The consequences include losing business to competitors, difficulties in introducing new technologies, lower net promoter scores (NPS), drop-in innovations, and increased workload on existing workers. Approximately $42.1 \%$ of experts revealed that no further measures are being taken to cope with these gaps. In contrast, other companies have changed work practices $(57.9 \%)$ and provided further training $(52.06 \%)$. The frequently mentioned competencies lacking were critical thinking, communications skills, social intelligence, understanding diversity, and the ability to understand business processes. As a result of these missing competencies, necessary action is needed to fill the gaps.

The Pareto chart reveals that inspecting and monitoring skills, critical thinking and decision making, interpersonal skills and empathy, basic data input and processing, communication skills, basic digital skills, basic data input and processing, complex information processing and interpretation, and creativity are key competencies of KWrs that modern organisation must focus on to overcome the current challenges. The KWrs can obtain these competencies via continuous on-the-job and deep learning through various means such as informal and formal training. Organisations have 


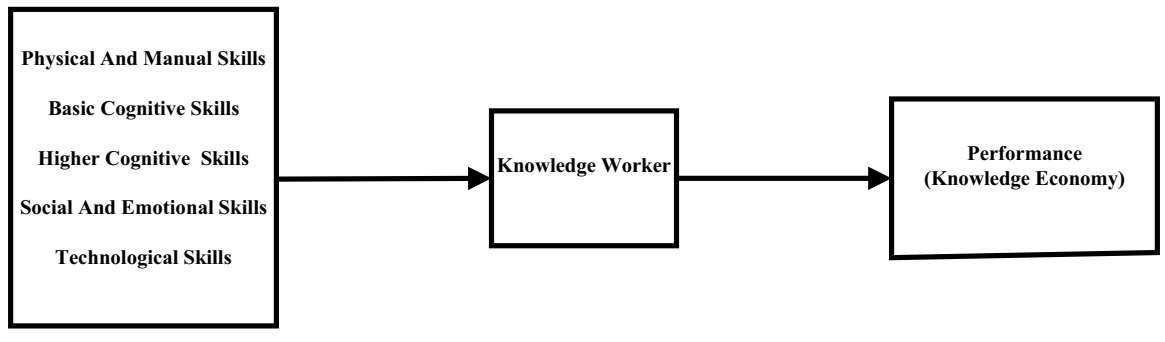

Fig. 8 The study framework

to move from a traditional centralised to a more decentralised learning approach, which supports KWrs in defining their learning path. Modern organisations must support learning approaches embedded in the normal working practices of KWrs and which are tailored to the requirements of the task and processes involved (Ley et al., 2008). Figure 8 shows the study framework.

Several agencies and statistical organisations conducted surveys that refer to the Assessing Skills and Competencies for Work in Knowledge Economy. For example, adult skills were assessed and analysed through the Programme for the International Assessment of Adult Competencies (PIAAC). The Survey of Adult Skills is the primary survey done as a part of PIAAC. The survey assesses people's proficiency in three critical information-processing skills: reading, numeracy, and problemsolving. It collects information and data on how adults apply their abilities at home, work, and in the broader community.

This international poll was undertaken in more than 40 countries or economies assessed the critical cognitive and workplace abilities required for individuals to engage in society and economies to prosper. The International Adult Literacy Survey (IALS) was undertaken in 20 countries or economies that participated in the first two rounds of the Survey of Adult Skills. On the other hand, six countries or economies participated in both the IALS and the Adult Literacy and Lifeskills (ALL) surveys (refer to Table 7). The IALS was conducted in three waves, with data collected in 1994, 1996, and 1998. Data collecting for the ALL began in 2003 and was completed in two rounds (Table 8).

Nevertheless, technological change and innovation propel the knowledge-based economy forward by altering manufacturing processes, consumer habits, and the economic structure. Both have experienced rapid growth in recent years. Specific changes in innovation processes would not have occurred without ICT. Conversely, the impact of some ICT may not have been felt in the absence of systemic changes. These changes have also affected how organisations operate. Some of the most agreed upon skills by different analysts are as follows:

- Communication skills (Carleton, 2011; Van Staden \& Du Toit, 2011; ViñasBardolet et al., 2020)

- Leadership capabilities (Bildstein et al., 2013; Atapattu \& Ranawake, 2017; Johannessen, 2021) 
Table 7 Countries participating in dates of data collection (PIAAC)

\begin{tabular}{llll}
\hline OECD countries and economies & IALS & ALL & PIAAC \\
\hline Australia & 1996 & $2006 / 2007$ & $2011 / 2012$ \\
Canada & 1994 & 2003 & $2011 / 2012$ \\
Chile & 1998 & - & $2014 / 2015$ \\
Czech Republic & 1998 & - & $2011 / 2012$ \\
Denmark & 1998 & - & $2011 / 2012$ \\
England (UK) & 1996 & - & $2011 / 2012$ \\
Finland & 1998 & - & $2011 / 2012$ \\
Flanders (Belgium) & 1996 & - & $2011 / 2012$ \\
Germany & 1994 & - & $2011 / 2012$ \\
Hungary & - & $2007 / 2008$ & $2017 / 2018$ \\
Ireland & 1996 & - & $2011 / 2012$ \\
Italy & 1998 & $2003 / 2004$ & $2011 / 2012$ \\
Netherlands & 1994 & $2007 / 2008$ & $2011 / 2012$ \\
New Zealand & 1996 & 2005 and 2007 & $2014 / 2015$ \\
Northern Ireland (UK) & 1996 & - & $2011 / 2012$ \\
Norway & 1998 & 2003 & $2011 / 2012$ \\
Poland & 1994 & - & $2011 / 2012$ \\
Slovenia & 1998 & - & $2014 / 2015$ \\
Sweden & 1994 & - & $2011 / 2012$ \\
United States & 1994 & 2003 & $2011 / 2012$ \\
\hline OECD Orgas & & \\
\hline
\end{tabular}

$O E C D$ Organisation for Economic Co-operation and Development, IALS International Adult Literacy Survey, ALL Adult Literacy and Lifeskills Surveys, PIAAC Programme for the International Assessment of Adult Competencies

Table 8 Core competencies assessed in the survey of adult skills (PIAAC)

\begin{tabular}{lll}
\hline Survey of adult skills (PIAAC) & ALL (2003-2007) & IALS (1994-1998) \\
\hline $\begin{array}{l}\text { Literacy (encompasses the reading of } \\
\text { prose and document texts as well as } \\
\text { digital texts) }\end{array}$ & $\begin{array}{l}\text { Literacy (rescaled to combine } \\
\text { prose and document } \\
\text { literacy) } \\
\text { Prose literacy } \\
\text { Document literacy }\end{array}$ & $\begin{array}{l}\text { Literacy (rescaled to combine } \\
\text { prose and document } \\
\text { literacy) } \\
\text { Prose literacy } \\
\text { Document literacy }\end{array}$ \\
$\begin{array}{l}\text { Reading components } \\
\text { Numeracy }\end{array}$ & Numeracy & \\
$\begin{array}{l}\text { Problem-solving in technology-rich } \\
\text { environments }\end{array}$ & & Quantitative literacy \\
& Problem-solving & \\
\hline
\end{tabular}

$O E C D$ Organisation for Economic Co-operation and Development, IALS International Adult Literacy Survey, ALL Adult Literacy and Lifeskills Surveys, PIAAC Programme for the International Assessment of Adult Competencies 
- Motivation and attitude (Bieńkowska \& Ignacek-Kuźnicka, 2019; Havupolku, 2017; Kraaij \& Spenner Crona, 2021)

- Problem-solving skills (Hämäläinen et al., 2019; Heavin \& Neville, 2008; Mládková, 2012)

- Analytical skills (Elkjaer, 2000; Sokół et al., 2017; Fujiwara, 2017; Grzybowska \& Łupicka, 2017)

The present changes are more rapid and unpredictable. Enterprises must react quickly to the business world's challenges and opportunities (Khazaei, 2020). Dynamic growth results from several processes, including internationalisation, technological advancement, and hyper-competition. The growing digitisation of the entire business results in more connectivity, competent workers, and fragile systems. Despite tremendous advancements in the industry, managers are constantly confronted with new challenges. By using new integrated systems, the future will be adaptable to the production of individualised products in small batch sizes. Dynamic business and engineering processes enable last-minute production changes and the ability to respond flexibly to disruptions in the industry. Therefore, it is circuital for KWrs to possess a strong foundation of relevant knowledge and skills with a high technical literacy level. On the one hand, acquiring recent and appropriate information is a must after leaving the original education process. Besides, the training system might serve as a foundation for becoming a $\mathrm{KWr}$ via the recruitment process, which is sometimes largely reliant on official diplomas in most nations. Simultaneously, individuals can acquire the necessary abilities to be classified as KWrs through experience, training, or more informal methods, all of which are extensively documented in the literature on informal or non-formal learning.

\section{Implications}

This study agrees that the firm's competence development depends on intangible assets such as skills, know-how, and path dependence. The KWrs must use different approaches to solve work issues, and creative solutions emerge when issues are reflected and looked at from diverse directions. They must have multiple intelligence and learning approaches such as physical intelligence, emotional intelligence, moral-ethical intelligence, and responsible decision (Cichocki \& Kuleshov, 2020). The KWrs must develop strong emotional and social competencies, including both higher and basic cognitive abilities, to successfully handle issues that arise at work. Advanced technological skills are a requirement in the modern economy but not necessarily a significant skill for KWrs.

Nevertheless, basic digital skills could be accounted as a 'must have' skill in today's knowledge economy. As most of the task involves a certain level of knowledge, predicting the scope of knowledge required to perform specific tasks at work since knowledge tasks are not structured is impossible (Bendkowski, 2018; Davenport, 2008). Therefore, KWrs must possess the necessary skills to learn while working, multitasking, and surfing the net in search of specific and appropriate answers to issues that arise. Knowledge works demands at least some 
basic cognitive competencies from KWrs to organise themselves at work, have basic knowledge of multiple disciplines, and collaborate and commit personally to tasks in a self-organised and autonomous structure. This study contributes to the body of knowledge on HRM, particularly competency-based management and talent management, which can help organisations, educational institutions, and researchers develop a competency-based framework or domain improvement and acquisition.

\section{Conclusions}

Due to the dynamic nature of the current business environment, most organisations cut across geographical boundaries; work in virtual space and across cultural, gender, and religious boundaries; and use a network of diverse collaborators or teams members. The KWr must have diverse interpersonal competencies, such as the ability to collaborate, a tolerance for ambiguity, and skills, which foster creativity at work to resolve work-related issues. As no one way exists to define solutions to a problem and the problem arises as they work, examining it from different perspectives gives a new point of view or a new fresh strategy to find a solution (Runco, 2014). On-the-job learning is a significant part of KWr activities requiring solid cognitive ability and organisation support (Bandura, 1999; Koehorst, 2020).

The cognitive style influences the individual's ability to handle and solve problems (Cunningham et al., 2002). Understanding these diverse competencies and approaches coupled with other interpersonal traits, such as conscientiousness and openness, may be important as it affects performance (Swift et al., 2020). The challenge is how these competencies can be acquired and retained. Both cognitive learning and emotional learning are vital in developing the competencies of a KWr (Cherniss et al., 1998). Nevertheless, cognitive skills can easily be learned, whereas emotional competencies involve not merely gaining information but changing the habits, characters, or unlearning a habit which is often a challenge. The primary contribution of this research is thus to present the required competencies of knowledge workers in the modern economy and demonstrate how these skills can be obtained. Understanding knowledge workers' skillsets and requirements could highlight the areas where organisations need to focus on. Practitioners at all levels can benefit from adopting varied talent management strategies and competencies that foster individual employee growth and add value to the organisation. Employee performance in a knowledge-based economy cannot be overlooked, making this study extremely important. By raising the cognitive level of human capabilities, both education and organisations can improve productivity and efficiency among workers.

In today's dynamic environment, organisations must develop their competencybased strategy imbedded with the key competencies discussed and act as facilitators rather than exerting direct control, which supports KWrs to continue using diverse learning approaches to solve issues at work (Jennings \& Wargnier, 2010; Sienkiewicz et al., 2014). The common approaches in which organisations have been assisting KWrs is by providing free access to KWrs to a broad range of services and information technology tools that they can use to develop their own 
working processes and needs, the systematic delivery of information and know-how to workers, which entails doing so within a well-defined framework of assignments and results (Davenport, 2011). Moreover, as autonomous workers, they often design their ways to gain knowledge and their task independently at their own pace. Traditional tools are not sufficient to support them.

Experiential learnings, innovative, and creative means are needed as KWrs have to solve the problem that arises at the very moment and cannot predict all the problems that will be encountered (Khazaei \& Tareq, 2021). Thus, the approach for gaining these professional competencies has to be trendy. Nevertheless, traditional educational institutions do not dispose of job-ready professionals with complete skills to meet the market demands, which also need to be refined (Gaižauskienè \& Tunčikienè, 2019; Surawski, 2019). Thus, the workers do not have to be delivered with prepared and ready competencies. Instead, they have to be provided with knowledge on solving and approaching problems and methods to identify novel solutions. The fundamental strategy for the process includes skills acquisition, competency development, knowledge management, and learning.

The growth of the knowledge economy is altering labour market demands for competencies and abilities (Choong \& Leung, 2021). Evidently, upskilling has occurred across the economies, partially due to increased demand for skills and partly due to higher educational attainment. The factors at work suggest that additional increases in general education levels are required. Consistent with the study findings, several observers have stated that workers must acquire new or extra abilities and skills. Not only a relevant degree of education is required to train KWrs properly, but they should also increase the likelihood of getting relevant and updated education related to the relevant industry.

Conclusively, based on existing evidence regarding general trends in competencies and their relationship to the knowledge economy, the ability to learn and adapt, problem-solving, programming skills, and the ability to search for information are the common key competencies for the KWrs. Moreover, the literature also suggests that high education levels and literacy are the primary competencies required in the knowledge economy. Basic general education equips workers with the fundamental intellectual and cognitive abilities necessary for productive participation. These essential abilities serve as a foundation for facilitating additional training and upgrading the specialised technical skills required of KWrs. Additional competencies that might be novel are increasingly more critical for KWrs linked to innovative organisational practices and KWrs. These job competencies can be viewed in future studies as a supplement to the competencies reviewed in this study. The study's findings will help policymakers make informed judgments about required competencies in the knowledge economy. The study's findings may be essential in offering insights into which skill sets would substantially impact the organisation when implemented. Appropriate policy actions can be taken to support the country's economic decisions. Universities and academic institutions might invest in programs that promote the development and improvement of these skills. On the theoretical aspect, knowledge on skill demands and good human resource management considerably minimise resistance to change and are likely to promote employees' intents to stay with the organisations. Further research may be conducted to give empirical findings in 
specific organisational contexts, talent management systems, and incorporation with knowledge management approaches.

Availability of Data and Material Not applicable.

Code Availability Not applicable.

\section{Declarations}

Ethics Approval Not applicable. Ethics approval was not required for this study as no personal data or information that could trace participant was not collected.

Consent to Participate Not applicable. Consent is not required as information is anonymised, and the submission does not include images that may identify the participant.

Consent for Publication Not applicable. Consent is not required as information is anonymised, and the submission does not include images that may identify the participant.

Conflict of Interest The author declares no competing interests.

Open Access This article is licensed under a Creative Commons Attribution 4.0 International License, which permits use, sharing, adaptation, distribution and reproduction in any medium or format, as long as you give appropriate credit to the original author(s) and the source, provide a link to the Creative Commons licence, and indicate if changes were made. The images or other third party material in this article are included in the article's Creative Commons licence, unless indicated otherwise in a credit line to the material. If material is not included in the article's Creative Commons licence and your intended use is not permitted by statutory regulation or exceeds the permitted use, you will need to obtain permission directly from the copyright holder. To view a copy of this licence, visit http://creativecommons.org/ licenses/by/4.0\%.

\section{References}

Acsente, D. (2010). Literature Review: A Representation of How Future Knowledge Worker is Shaping the Twenty-First Century Workplace. https://doi.org/10.1108/10748121011072726

Alvesson, M. (2004). Knowledge work and knowledge-intensive firms. OUP Oxford.

Armstrong, M., \& Taylor, S. (2017). Armstrong's handbook of human resource management practice. Kogan Page.

Atapattu, M., \& Ranawake, G. (2017). Transformational and transactional leadership behaviours and their effect on knowledge workers' propensity for knowledge management processes. Journal of Information \& Knowledge Management, 16(03), 1750026.

Atapattu, M. (2018). High performance work practices and knowledge workers' propensity for knowledge management processes. Knowledge Management Research \& Practice, 16(3), 356-365.

Bieńkowska, A., \& Ignacek-Kuźnicka, B. (2019). Influence of knowledge workers work motivation on their job performance-Results of empirical research. Central European Business Review, 8(5).

Bildstein, I., Gueldenberg, S., \& Tjitra, H. (2013). Effective leadership of knowledge workers: Results of an intercultural business study. Management Research Review.

Baena, F., Guarin, A., Mora, J., Sauza, J., \& Retat, S. (2017). Learning factory: The path to industry 4.0. Procedia Manufacturing. https://doi.org/10.1016/j.promfg.2017.04.022

Bakule, M., Czesana, V., Havlickova, V., Kriechel, B., Rasovec, T., \& Wilson, R. (2016). Guide to anticipating and matching skills and jobs volume 2 developing skills foresights, scenarios and forecasts. Cedefop, 2. https://doi.org/10.2816/867049 
Bandura, A. (1999). Social cognitive theory: An agentic perspective. In Asian Journal of Social Psychology, 2(1), 21-41. Blackwell Publishing Ltd. https://doi.org/10.1111/1467-839X.00024

Bendkowski, J. (2018). Developing employees competencies in virtual economy. Scientific Papers of Silesian University of Technology. Organization and Management Series, 2018(121), 11-24. https://doi. org/10.29119/1641-3466.2018.121.1

Benson, T. (2016). Motivating millennials takes more than flexible work policies. Harvard Business Review. https://hbr.org/2016/02/motivating-millennials-takes-more-than-flexible-work-policies. Accessed 17 April 2021.

Bhasin, P., Bohle, D., Hall, D., Hall, P., Helleiner, E., Kirshner, J., Lee, M., Nesvetailova, A., Ornston, D., Palan, R., Soskice, D., \& Swenson, P. (2021). Global secular stagnation and the rise of intellectual property monopoly acknowledgements: Randall Germain most of all. http://orcid.org/ 0000-0002-5571-3644

Bontje, M., Musterd, S., \& Sleutjes, B. (2017). Skills and cities: Knowledge workers in NorthwestEuropean cities. International Journal of Knowledge-Based Development, 8(2), 135-153. https:// doi.org/10.1504/IJKBD.2017.085152

Boyatzis, R. E., \& Dubuc, P. (1982). The competent manager: A model for effective performance. Wiley. ISBN: 978-0-471-09031-1

Bughin, J., Hazan, E., Lund, S., Dahlström, P., Wiesinger, A., \& Subramaniam, A. (2018). Skill shift: Automation and the workforce of the future I McKinsey. McKinsey Global Institute. https://www. mckinsey.com/featured-insights/future-of-work/skill-shift-automation-and-the-future-of-theworkforce\#. Accessed 1 May 2021.

Carayannis, E. G., \& Campbell, D. F. J. (2011). Open innovation diplomacy and a 21st century Fractal Research, Education and Innovation (FREIE) Ecosystem: Building on the quadruple and quintuple helix innovation concepts and the "Mode 3" knowledge production system. Journal of the Knowledge Economy, 2(3), 327-372. https://doi.org/10.1007/s13132-011-0058-3

Carleton Edmonton, K. (2011). How to motivate and retain knowledge workers in organizations: A review of the literature. In International Journal of Management, 28(2). https://roam.macewan.ca/ islandora/object/gm:215. Accessed 3 May 2021.

Carleton, K. (2011). How to motivate and retain knowledge workers in organizations: A review of the literature.

Ceesay, L. B. (2020). Building a high customer experience management organization: Toward customercentricity. Jindal Journal of Business Research, 9(2), 162-175. https://doi.org/10.1177/2278682120968983

Chen, A., \& Edgington, T. M. (2005). Assessing value in organizational knowledge creation: Considerations for knowledge workers. MIS Quarterly, 29(2), 279-309.

Chen, L., Wadei, K. A., Bai, S., \& Liu, J. (2020). Participative leadership and employee creativity: A sequential mediation model of psychological safety and creative process engagement. Leadership and Organization Development Journal, 41(6), 741-759. https://doi.org/10.1108/LODJ-07-2019-0319

Cherniss, C., Goleman, D., Emmerling, R., Cowan, K., \& Adler, M. (1998). Bringing emotional intelligence to the workplace a technical report issued by the consortium for research on emotional intelligence in organizations. www.eiconsortium.org. Accessed 26 May 2021.

Choong, K. K., \& Leung, P. W. (2021). A critical review of the precursors of the knowledge economy and their contemporary research: Implications for the computerized new economy. Journal of the Knowledge Economy, 1-38. https://doi.org/10.1007/S13132-021-00734-9/TABLES/5

Cichocki, A., \& Kuleshov, A. P. (2020). Future trends for human-ai collaboration: A comprehensive taxonomy of AI/AGI using multiple intelligences and learning styles. ArXiv. http://arxiv.org/abs/2008. 04793. Accessed 28 April 2021.

Cichocki, A., \& Kuleshov, A. P. (2021). Future trends for human-ai collaboration: A comprehensive taxonomy of AI/AGI Using Multiple Intelligences and Learning Styles. In Computational Intelligence and Neuroscience (Vol. 2021). Hindawi Limited. https://doi.org/10.1155/2021/8893795

Colomo-Palacios, R., Cabezas-Isla, F., García-Crespo, Á., \& Soto-Acosta, P. (2010). Generic competences for the IT knowledge workers: A study from the field. In World Summit on Knowledge Society, 1-7. Springer, Berlin, Heidelberg.

Crossan, M. M., Maurer, C. C., \& White, R. E. (2011). Reflections on the 2009 AMR decade award: Do we have a theory of organizational learning? Academy of Management Review, 36(3), 446-460. https://doi.org/10.5465/amr.2010.0544

Crossan, M. M., Lane, H. W., \& White, R. E. (1999). An organizational learning Framework: From intuition to institution. The Academy of Management Review, 24(3), 522. https://doi.org/10.2307/ 259140 
Cunningham, B. J., Gerrard, P., Schoch, H., \& Hong, C. L. (2002). An entrepreneurial logic for the new economy. Management Decision, 40(8), 734-744. https://doi.org/10.1108/00251740210437707

Davenport, T. H. (2011). Rethinking knowledge work: A strategic approach. McKinsey Quarterly. https://www.mckinsey.com/ /media/McKinsey/BusinessFunctions/Organization/OurInsights/ RethinkingknowledgeworkAstrategicapproach/RethinkingknowledgeworkAstrategicapproach.pdf. Accessed 18 April 2021.

Davenport, T. H. (2005). Thinking for a Living.

Davenport, T. H. (2008). Improving knowledge worker performance. In From strategy to execution: Turning accelerated global change into opportunity, 215-235. Springer Berlin Heidelberg. https://doi. org/10.1007/978-3-540-71880-2_11

Ddi. (2015). Talent assessment strategies: A decision guide for organizational performance. Aberdeen Group.

De Jong, J., Blomme, R. J., \& Lub, X. D. (2018). Unlocking the potential of outsourcing, the key: Authentic leadership as accelerator of open innovation. International Journal of Business and Globalisation, 20(4), 557-577. https://doi.org/10.1504/IJBG.2018.093601

De Munck, B. (2019). Artisans as knowledge workers: Craft and creativity in a long term perspective. Geoforum, 99, 227-237. https://doi.org/10.1016/j.geoforum.2018.05.025

De Sordi, J. O., de Azevedo, M. C., Bianchi, E. M. P. G., \& Carandina, T. (2021). Defining the term knowledge worker: Toward improved ontology and operationalization. Knowledge and Process Management, 28(1), 56-70. https://doi.org/10.1002/kpm.1647

Denning, S. (2021). Why management models are crucial to the success of business models. Strategy and Leadership. https://doi.org/10.1108/SL-02-2021-0011

Drucker, P. F. (1969). The age of discontinuity. Elsevier. https://doi.org/10.1016/c2013-0-04383-6

Dubina, I. N., Carayannis, E. G., \& Campbell, D. F. J. (2012). Creativity economy and a crisis of the economy? Coevolution of knowledge, innovation, and creativity, and of the knowledge economy and knowledge society. Journal of the Knowledge Economy, 3(1), 1-24. https://doi.org/10.1007/ s13132-011-0042-y

Edelbroek, R., Peters, P., \& Blomme, R. J. (2019). Engaging in open innovation: The mediating role of work engagement in the relationship between transformational and transactional leadership and the quality of the open innovation process as perceived by employees. Journal of General Management, 45(1), 5-17. https://doi.org/10.1177/0306307019844633

Ehin, C. (2008). Un-managing knowledge workers. Journal of Intellectual Capital, 9(3), 337-350. https:// doi.org/10.1108/14691930810891965

Elkjaer, B. (2000). Learning and getting to know: The case of knowledge workers. Human Resource Development International, 3(3), 343-359.

Frey, C. B., \& Osborne, M. A. (2017). The future of employment: How susceptible are jobs to computerisation? Technological Forecasting and Social Change, 114, 254-280. https://doi.org/10.1016/j. techfore.2016.08.019

Fujiwara, A. (2017). The knowledge spillover resulting from the mobility of knowledge workers. In 20176 th International Conference on Industrial Technology and Management (ICITM), 181-191. IEEE.

Fu-Sheng, T. S. A. I., Chin-Chiung, K. U. O., \& Chi-Fang, L. I. U. (2017). Knowledge-based view in the franchising research literature. Journal of Economic and Social Thought, 4(1), 97-107.

Gaižauskienè, L., \& Tunčikienè, Ž. (2019). Organizational level factors of knowledge workerworkplace fit: Identifying the key drivers. Open Economics, 1(1), 167-178. https://doi.org/10.1515/ openec-2018-0010

Goleman, D. (2011). Leadership: The power of emotional intelligence. More Than Sound LLC. http://dspace. vnbrims.org:13000/jspui/bitstream/123456789/4733/1/LeadershipThePowerofEmotionalIntellegence. pdf. Accessed 25 May 2021.

Grant, R. M. (1991). The resource-based theory of competitive advantage: Implications for strategy formulation. California Management Review, 33(3), 114-135. https://doi.org/10.2307/41166664

Greif, A. (2006a). Institutional dynamics as a historical process. In Institutions and the path to the modern economy: Lessons from Medieval trade, 153-157. Cambridge University Press. https:// doi.org/10.1017/CBO9780511791307.008

Greif, A. (2006b). Institutional trajectories: How past institutions affect current ones. In Institutions and the path to the modern economy: Lessons from Medieval trade, 187-216. Cambridge University Press. https://doi.org/10.1017/CBO9780511791307.010

Grover, V., Teng, J. T. C., Segars, A. H., \& Fiedler, K. D. (1998). The influence of information technology diffusion and business process change on perceived productivity: The IS executive's 
perspective. Information and Management, 34(3), 141-159. https://doi.org/10.1016/S03787206(98)00054-8

Grzybowska, K., \& Łupicka, A. (2017). Key competencies for Industry 4.0. Economics \& Management Innovations, 1(1), 250-253.

Gumusluoglu, L., \& Ilsev, A. (2009). Transformational leadership, creativity, and organizational innovation. Journal of Business Research, 62(4), 461-473. https://doi.org/10.1016/j.jbusres.2007. 07.032

Hammer, M., Leonard, D., \& Davenport, T. (2004). Why don't we know more about knowledge? MITSloan Management Review. https://sloanreview.mit.edu/article/why-dont-we-know-more-aboutknowledge/. Accessed 3 May 2021.

Healy, K. (2002). What's new for culture in the new economy? Journal of Arts Management Law and Society, 32(2), 86-103. https://doi.org/10.1080/10632920209596967

Hendarman, A. F., \& Tjakraatmadja, J. H. (2012). Relationship among soft skills, hard skills, and innovativeness of knowledge workers in the knowledge economy era. Procedia - Social and Behavioral Sciences, 52, 35-44. https://doi.org/10.1016/j.sbspro.2012.09.439

Horibe, F. (1999). Managing knowledge workers: New skills and attitudes to unlock the intellectual capital in your organization. Undefined.

Hämäläinen, R., De Wever, B., Nissinen, K., \& Cincinnato, S. (2019). What makes the differencePIAAC as a resource for understanding the problem-solving skills of Europe's higher-education adults. Computers \& Education, 129, 27-36.

Heavin, C., \& Neville, K. (2008). Mentoring knowledge workers. In Knowledge management: concepts, methodologies, tools, and applications. IGI Global, 1223-1230.

Havupolku, S. M. (2017). Work motivation and innovative work behaviour among knowledge workers: How intrinsically motivated employees are ready to generate, promote and realise new ideas.

Jemielniak, D. (2012a). The new knowledge workers. In the New Knowledge Workers. https://doi.org/10. 4337/9780857933119

Jemielniak, D. (2012b). The new knowledge workers. Edward Elgar Publishing Ltd. https://doi.org/10. 4337/9780857933119

Jennings, C., \& Wargnier, J. (2010). Experiential learning — A way to develop agile minds in the knowledge economy? Development and Learning in Organisations, 24(3), 14-16. https://doi.org/10. $1108 / 14777281011037245$

Johannessen, J. A. (2021). Leadership tools to increase the motivation of knowledge workers. Continuous Change and Communication in Knowledge Management.

Jones, G. (2017). Business history, the great divergence and the great convergence.

Joseph, R. (2004). The knowledge worker: Getting the organizational and informational balance right: A review. Innovation, 6(1), 85-97. https://doi.org/10.5172/impp.2004.6.1.85

Kane, G. C. (2015). Are you ready for the certainty of unknown? MIT Sloan Management Review, 56(3), 0. https://search.proquest.com/scholarly-journals/are-you-ready-certainty-unknown/docview/ 1670982090/se-2?accountid=49011. Accessed 17 April 2021.

Khazaei, H. (2019a). Influence of career development and training budget on employee retention in manufacturing sector in Penang Malaysia.

Khazaei, H. (2019b). The datasets of factors influencing adoption of electric cars in Malaysia: A structural equation modelling (SEM) analysis. Data in Brief, 27, 104644.

Khazaei, H., \& Tareq, M. A. (2021). Moderating effects of personal innovativeness and driving experience on factors influencing adoption of BEVs in Malaysia: An integrated SEM-BSEM approach. Heliyon, 7(9), e08072.

Khazaei, H. (2020). Integrating cognitive antecedents to UTAUT model to explain adoption of blockchain technology among Malaysian SMEs. JOIV: International Journal on Informatics Visualization, $4(2), 85-90$.

Kochhar, R. (2020). Emerging jobs, green economy boost U.S. demand for analytical skills I Pew Research Center. https://www.pewresearch.org/fact-tank/2020/03/23/new-emerging-jobs-and-thegreen-economy-are-boosting-demand-for-analytical-skills/

Koehorst, M. (2020). Modernizing Creative Work How Organizations in the Creative Industries Can Support Knowledge Workers to Develop the Skills They Need. https://doi.org/10.3990/1.9789036550895

Kotsemir, M. N., \& Meissner, D. (2013). Conceptualizing the innovation process - trends and outlook. SSRN Electronic Journal. https://doi.org/10.2139/ssrn.2249782

Kraaij, E., \& Spenner Crona, H. (2021). The feeling of a lost community-A case study of how knowledge workers interpret motivation when working from home due to COVID-19. 
Kraken, F., Schlagwein, D., \& Schoder, D. (2020). Resource openness: Towards an integrated theoretical approach. Academy of Management Proceedings, 2020(1), 19460. https://doi.org/10.5465/ambpp. 2020.19460abstract

Kudyba, S., Fjermestad, J., \& Davenport, T. (2020). A research model for identifying factors that drive effective decision-making and the future of work. Journal of Intellectual Capital, 21(6), 835-851. https://doi.org/10.1108/JIC-05-2019-0130

Lampe, C., \& Ellison, N. B. (2016). How Americans use social media at work I Pew Research Center. Pew Research. https://www.pewresearch.org/internet/2016/06/22/social-media-and-the-workplace/. Accessed 22 April 2021.

Lee, S. Y., \& Lee, S. W. (2020). Social media use and job performance in the workplace: The effects of Facebook and KakaoTalk yse on job performance in South Korea. Sustainability, 12(10), 4052. https://doi.org/10.3390/su12104052

Ley, T., Ulbrich, A., Scheir, P., Lindstaedt, S. N., Kump, B., \& Albert, D. (2008). Modeling competencies for supporting work-integrated learning in knowledge work. Journal of Knowledge Management, 12(6), 31-47. https://doi.org/10.1108/13673270810913603

Madden, M., \& Jones, S. (2008). Networked Workers I Pew Research Center. PEW Research. https://www. pewresearch.org/internet/2008/09/24/networked-workers/. Accessed 25 May 2021.

Małachowski, B. (2011). Competence-based management of knowledge workers in project-oriented organizations. Lecture Notes in Computer Science (Including Subseries Lecture Notes in Artificial Intelligence and Lecture Notes in Bioinformatics), 7091 LNAI, 281-292. https://doi.org/10.1007/ 978-3-642-25975-3_25

Mankins, M., \& Garton, E. (2017). How Spotify balances employee autonomy and accountability. Harvard Business Review. https://hbr.org/2017/02/how-spotify-balances-employee-autonomy-andaccountability. Accessed 17 May 2021.

Manyika, J., Chui, M., Bughin, J., Dobbs, R., Bisson, P., \& Marrs, A. (2013). Disruptive technologies: Advances that will transform life, business, and the global economy. www.mckinsey.com/mgi. Accessed 1 May 2021.

Manyika, J., Lund, S., Bughin, J., Woetzel, J., Stamenov, K., \& Dhingra, D. (2016). Digital globalization: The new era of global flows. https://www.mckinsey.com/ /media/McKinsey/BusinessFunctions/ McKinseyDigital/OurInsights/DigitalglobalizationTheneweraofglobalflows/MGI-Digitalglobalization-Full-report.ashx. Accessed 21 April 2021.

Maruta, R. (2012). Transforming knowledge workers into innovation workers to improve corporate productivity. Knowledge-Based Systems, 30, 35-47. https://doi.org/10.1016/j.knosys.2011.06.017

McKinsey. (2017). ING's agile transformation I McKinsey. McKinsey Quarterly. https://www.mckinsey. com/industries/financial-services/our-insights/ings-agile-transformation. Accessed 17 May 2021.

Mintullabo, N., Earunt, C., \& Doluptmolorpo, V. (2019). OSAAMINEN 2035: Osaamisen ennakointifoorumin ensimmäisiä ennakointituloksia. National Board of Education. www.oph.fi. Accessed 8 May 2021.

Mládková, L. (2012). Leadership in management of knowledge workers. Procedia-Social and Behavioral Sciences, 41, 243-250.

Nickols, F. (2016). Drucker's dictums. www.nickols.us. Accessed 8 May 2021.

Nocks, L. (2021). Learn who we have to thank for the term work-life balance - IEEE Spectrum. https:// spectrum.ieee.org/the-institute/ieee-history/learn-who-we-have-to-thank-for-the-term-worklifebalance. Accessed 24 April 2021.

Parmelee, M. (2020). Millennial Survey 2020 | Deloitte Global. Deloitte. https:/www2.deloitte.com/ global/en/pages/about-deloitte/articles/millennialsurvey.html. Accessed 17 April 2021.

Peng, W. (2009). Review of the study on definition, characters and classification of knowledge worker. https://en.cnki.com.cn/Article_en/CJFDTotal-GLXB200902024.htm. Accessed 8 May 2021.

Perkin, N. (2017). Agile transformation at ING - A case study — business agility. Agile Business Manifesto. https://agilebusinessmanifesto.com/agilebusiness/agile-transformation-at-ing/. Accessed 17 May 2021.

Pont, B. (2001). Competencies for the knowledge economy.

Popper, R. (2008). How are foresight methods selected? https://doi.org/10.1108/14636680810918586

Prahalad, C. K., \& Hamel, G. (1990). The core competence and the corporation. Harvard Business Review.

Prahalad, C. K., \& Hamel, G. (1997). The core competence of the corporation. Strategische Unternehmungsplanung / Strategische Unternehmungsführung (pp. 969-987). https://doi.org/10.1007/9783-662-41482-8_46 
Pyöriä, P. (2005). The concept of knowledge work revisited. Journal of Knowledge Management, 9(3), 116-127. https://doi.org/10.1108/13673270510602818

Rainie, L., \& Wellman, B. (2018). The new social operating system of networked individualism. The MIT Press. https://doi.org/10.7551/mitpress/8358.003.0005

Rechberg, I. D. W. (2020). Emotional intelligence and knowledge management: A necessary link? Knowledge and Process Management, 27(1), 15-24. https://doi.org/10.1002/kpm.1625

Roth, C. (2019). Gartner blog network. Gartner. https://blogs.gartner.com/craig-roth/2019/12/11/2019exceeded-1-billion-knowledge-workers/. Accessed 18 April 2021.

Runco, M. A. (2014). Personality and motivation. In Creativity, 265-302. Elsevier. https://doi.org/10. 1016/b978-0-12-410512-6.00009-6. Accessed 26 May 2021.

Schatsky, D., Muraskin, C., \& Gurumurthy, R. (2015). Cognitive technologies: The real opportunities for business I Deloitte Insights. In Deloitte Review, (16). https://www2.deloitte.com/us/en/insights/ deloitte-review/issue-16/cognitive-technologies-business-applications.html. Accessed 3 May 2021.

Schoder, D., Schlagwein, D., \& Fischbach, K. (2019). Open Resource-Based View (ORBV): A theory of resource openness. ICIS 2019 Proceedings. https://aisel.aisnet.org/icis2019/research_methods/ research_methods/9. Accessed 26 April 2021.

Scully-Russ, E., \& Torraco, R. (2020). The changing nature and organization of work: An integrative review of the literature. Human Resource Development Review, 19(1), 66-93. https://doi.org/10. $1177 / 1534484319886394$

Servoz, M. (2019). The future of work? Work of the future! In European Comission Report. https://doi. org/10.2872/50454

Sienkiewicz, Ł., Jawor-Joniewicz, A., Sajkiewicz Katarzyna Trawińska-Konador Krzysztof Podwójcic, B., Chłon-Domińczak, A., Sitek, M., \& Wiewióra, A. (2014). Competency-based human resources management: The lifelong learning perspective. www.ibe.edu.pl. Accessed 23 June 2021.

Sjöblom, K. (2020). Flourishing in 21st century workplaces : How to support knowledge workers' productivity and well-being in modern environments. https://helda.helsinki.fi/handle/10138/314728. Accessed 4 June 2021.

Snowden, D. J., \& Boone, M. E. (2007). A leader's framework for decision making. Harvard Business Review, 85(11). https://pubmed.ncbi.nlm.nih.gov/18159787/. Accessed 26 April 2021.

Spencer, L. M., Spencer, L. M., Spencer, S. M., \& Books24x7, I. (1993). Competence at work: Models for superior performance. Wiley.

Sokół, A., Figurska, I., \& Tvaronavičienė, M. (2017). Creativity as one of the core competencies of studying knowledge workers. Entrepreneurship and Sustainability Issues, 5(1), 23-35. https://doi.org/ 10.9770/jesi.2017.5.1(2)

Statista. (2020). • Global crowdfunding market size 2019 and 2026 I Statista. Statista Research Department. https://www.statista.com/statistics/1078273/global-crowdfunding-market-size/. Accessed 22 April 2021.

Stiroh, K. (1999). Is there a new economy? Challenge, 42(4), 82-101. https://doi.org/10.1080/05775132. 1999.11472112

Surawski, B. (2019). Who is a "knowledge worker" - Clarifying the meaning of the term through comparison with synonymous and associated terms. Management, 23(1), 105-133. https://doi.org/10. 2478/manment-2019-0007

Swift, V., Wilson, K. E., \& Peterson, J. B. (2020). Zooming in on the attentional foundations of the Big Five. Personality and Individual Differences, 164, 110000. https://doi.org/10.1016/j.paid.2020. 110000

Tankovska, H. (2021). Social media - Statistics \& facts I Statista. Statista. https://www.statista.com/topics/1164/social-networks/. Accessed 22 April 2021.

Tapscott, D. (1996). The digital economy: Promise and peril in the age of networked intelligence. McGraw-Hill.

Tareq, M. A., Khazaei, H., \& Khazaei, A. (2017). Emotional intelligence and charismatic leadership. Innovation and Management.

Teece, D. J., Pisano, G., \& Shuen, A. (1997). Dynamic capabilities and strategic management. Strategic Management Journal, 18(7), 509-533. https://doi.org/10.1002/(SICI)1097-0266(199708)18:7\% 3c509::AID-SMJ882\%3e3.0.CO;2-Z

Tsai, M.-T., Chen, C.-C., \& Chin, C.-W. (2010). Knowledge workers' interpersonal skills and innovation performance: An empirical study of Taiwanese high-tech industrial qorkers. Social Behavior and Personality: An International Journal, 38(1), 115-126. https://doi.org/10.2224/sbp.2010.38.1.115 
Tsoukas, H. (2009). A dialogical approach to the creation of new knowledge in organizations. Organization Science, 20(6), 941-957. https://doi.org/10.1287/orsc.1090.0435

Väänänen, A., Toivanen, M., \& Lallukka, T. (2020). Lost in autonomy - Temporal structures and their implications for employees' autonomy and well-being among knowledge workers. Occupational Health Science, 4(1-2), 83-101. https://doi.org/10.1007/s41542-020-00058-1

Van Staden, R., \& Du Toit, A. (2011). Career development of South African knowledge workers. South African Journal of Economic and Management Sciences, 14(1), 80-91.

van Laar, E., van Deursen, A. J. A. M., van Dijk, J. A. G. M., \& de Haan, J. (2020). Determinants of 21stcentury skills and 21st-century digital skills for workers: A systematic literature review. In SAGE Open (Vol. 10, Issue 1). SAGE Publications Inc. https://doi.org/10.1177/2158244019900176

Van Laar, E., Van Deursen, A. J. A. M., Van Dijk, J. A. G. M., \& De Haan, J. (2017). The relation between 21st-century skills and digital skills: A systematic literature review. https://doi.org/10. 1016/j.chb.2017.03.010

Viñas-Bardolet, C., Torrent-Sellens, J., \& Guillen-Royo, M. (2020). Knowledge workers and job satisfaction: Evidence from Europe. Journal of the Knowledge Economy, 11(1), 256-280.

Wadei, K. A., Lu, C., \& Wu, W. (2021). Unpacking the chain mediation process between transformational leadership and knowledge worker creative performance: Evidence from China. Chinese Management Studies, 15(2), 483-498. https://doi.org/10.1108/CMS-03-2020-0118

Wallach, O. (2020). The history of the gaming industry in one chart I World Economic Forum. WEFORUM. https://www.weforum.org/agenda/2020/11/gaming-games-consels-xbox-play-station-fun/WEFORUM. The future of jobs report 2020.

Weil, D. (2014). The fissured workplace. Harvard University Press. http://www.jstor.org/stable/j. ctt6wppdw

Wernerfelt, B. (1984). A resource-based view of the firm. Strategic Management Journal, 5(2), 171-180. http://www.jstor.org/stable/2486175

Whiting, K. (2020). What are the top 10 job skills for the future? I World Economic Forum. WEFORUM. https://www.weforum.org/agenda/2020/10/top-10-work-skills-of-tomorrow-how-long-it-takes-tolearn-them/. Accessed 14 May 2021.

Wittel, A. (2001). Toward a network sociality. Theory, Culture \& Society, 18(6), 51-76. https://doi.org/ $10.1177 / 026327601018006003$

Wuttaphan, N. (2017). Human capital theory: The theory of human resource development, implications, and future. Rajabhat Journal of Sciences, Humanities \& Social Sciences, 18(2), 240-253.

Publisher's Note Springer Nature remains neutral with regard to jurisdictional claims in published maps and institutional affiliations. 